\title{
Gas hydrate destabilization and methane release events in the Krishna-Godavari basin, Bay of Bengal
}

\author{
R. K. Joshi ${ }^{1}$, A. Mazumdar,, ${ }^{2}$, A. Peketi ${ }^{3}$, P. B. Ramamurty ${ }^{4}$, B. G. Naik $^{2}$, M. Kocherla ${ }^{2}$, Mary \\ Ann Carvalho ${ }^{2}$, P. Mahalakshmi ${ }^{2}$, P. Dewangan ${ }^{2}$ and M. V. Ramana ${ }^{2}$ \\ ${ }^{1}$ Geological Survey of India \\ Kolkata-700 091, India \\ ${ }^{2}$ CSIR-National Institute of Oceanography \\ Dona Paula, Goa-403 004, India \\ *maninda@nio.org (corresponding) \\ ${ }^{3}$ Physical Research Laboratory, \\ Ahmedabad, Gujarat-3800 09, India \\ ${ }^{4}$ National Geophysical Research Institute \\ Uppal Road, Hyderabad-500 606, Andhra Pradesh, India
}

\begin{abstract}
Methane release events have been linked to global warming, alteration of the carbon cycle and influence on biota. However, unequivocal evidence of paleomethane release events are limited. We report several negative carbon stable isotope excursions in planktic and benthic foraminifera in a core (MD161-8) from the Krishna-Godavari (K-G) Basin, Bay of Bengal. The most negative $\delta^{13} \mathrm{C}$ spikes are recorded during the marine isotope stages MIS-4 and at the transition of MIS-5 to 4 . Occurrence of highly ${ }^{13} \mathrm{C}$ depleted (average $\delta^{13} \mathrm{C}=-48 \pm 2.4 \%$ VPDB) authigenic high magnesian calcite are also reported within this time window from the core MD161-8. In the present work an unequivocal explanation for the observed ${ }^{13} \mathrm{C}$ depletion in the marine planktic and benthic foraminifera is difficult to achieve solely from the optical/ electron microscopy or $\mathrm{C}-\mathrm{O}$ stable isotope ratio analyses due to possible influence of diagenetic alteration. We attribute the observed episodic methane expulsion events, as inferred from the negative $\delta^{13} \mathrm{C}$ excursions and earlier reports on the occurrence chemosynthetic bivalves and Mo concentration anomaly to the destabilization of the base of gas hydrate stability zone (BGHSZ). Sea level drop and shale tectonics induced focused fluid flow are the two possible causes of hydrate destabilization discussed here. Shale tectonics were possibly responsible for creating fault systems which acted as the conduit for gas flow through the sediment column and subsequent seepage. Shale and salt tectonics in the passive continental margins being a globally observed phenomenon, its role as an important driving force for enhanced methane emission needs detailed investigation to understand the climatic perturbations through geologic time. Additional evidence of methane emission from site MD161-15 further supports the link between shale tectonics and methane emission.
\end{abstract}

Key words: methane emission, gas hydrate, shale tectonics, carbon isotope, oxygen isotope, passive margin 


\section{Introduction}

Perturbation in methane concentrations in the ocean-atmosphere system may cause global warming (Lashof and Ahuja, 1990) and alteration of the carbon cycle (Dickens, 2003). Vast reserves of methane hydrate, a crystalline form of methane-water complex (molar ratio 1:6) exist within the marine sediments at suitable temperature-pressure conditions subject to the availability of methane in excess of solubility (Kvenvolden, 1993; Sloan, 1998; Kvenvolden and Lorenson, 2001). Whereas, methane from shallow sub-seafloor (Hovland and Judd, 1992; Mazumdar et al., 2009a; Coffin et al., 2013) are additional sources of marine methane to the global budget.The terrestrial sources influencing the global methane budget include volcanic eruptions, natural wetlands, rice and paddy fields, enteric fermentation, coal mining, biomass burning, soil microseepage, geothermal activity (Chanton and Whiting, 1996; Judd et al., 2002; Kaplan, 2002; Etiope et al., 2008; Sanchez Goni et al., 2008) and ebullition from thermokarst lakes (Walter et al., 2006). Carbon stable isotope ratios of foraminifera (Kennett and Stott, 1991; Kennett et al., 2000; Kennett et al., 2003; De Garidel-Thoron et al., 2004; Hill et al., 2004a; Uchida et al., 2004; Cook et al., 2011) as well as measurement of methane concentrations in the Greenland and Antarctic ice deposits (Chappellaz et al.,1997; Dällenbach et al.,2000; Wolf and Spahni, 2007) suggest repeated enrichment of methane concentrations in the ocean-atmosphere system. Methane enrichment has primarily been attributed to the hydrate destabilization due to increase in marine bottom water temperature during interstadials (Kennett et al., 2003; De Gadriel-Thoron et al., 2004), depressurization from lowering of sea level or slope failure (Buffett and Archer, 2004; Archer, 2007).

Marked enrichment in methane concentrations in ancient water column/ atmosphere has been inferred from the late Neoproterozoic (Kennedy et al., 2008), early Jurassic (Kemp et al., 2005), early Cretaceous (Jahren et al., 2001), Paleocene-Eocene (Dickens et al., 1995), Miocene (Panieri et al., 2009) and late Quaternary (Kennett et al., 2000; Hinrichs et al., 2003; De-Gadriel-Thoron et al., 2004). Methane enrichment episodes prior to Preborial-Younger Dryas transition has primarily been attributed to methane hydrate destabilization (Kennett et al., 2003). In contrast, $\delta D_{\mathrm{CH} 4}$ (Sowers, 2006; Bock et al., 2010) and ${ }^{14} \mathrm{CH}_{4}$ (Petrenko et al., 2009) data from ice cores, suggest that marine methane hydrate degassing may not be the cause of atmospheric methane enrichment intervals through late Quaternary. Although, a significant volume of work (Wefer et al.,1994; Kennett et al., 2000; Smith et al., 2001; Hill et al., 2003; Kennett et al., 2003; De-Gadriel-Thoron et al., 2004; Panieri et al., 2012; Wang et al., 2013) correlate ${ }^{13} \mathrm{C}$ depletion in planktic and benthic foraminifera to ${ }^{13} \mathrm{C}$ depleted bicarbonate ion produced via 
aerobic/ anaerobic oxidation of methane in water column/ sediment-water interface, a significant number of publications attribute the ${ }^{13} \mathrm{C}$ depletion to diagenetic alteration of non-living foraminifera (Martin et al., 2004; Ohkushi et al., 2005; Wiedicke and Weiss, 2006; Uchida et al, 2008; Torres et al., 2010 and Cook et al., 2011; Herguera et al., 2014). Diagenesis results in precipitation of authigenic carbonate into the shell cavities or recrystallisation of shell ultrastructure. The controversy regarding the

${ }^{13} \mathrm{C}$ depletion in foraminifera and latter's association with methane emission is primarily due to the lack of routine/ rapid methods for unequivocal selection of unaltered foraminifera shells. It is also difficult to understand cryptic alterations in apparently clean shells which may result in significant ${ }^{13} \mathrm{C}$ depletion.

We present here, carbon-oxygen stable isotope ratios of planktic and benthic foraminifera and carbon isotope ratios of sediment organic matter and lipid extracts in a sediment core (MD161-8) from the Krishna-Godavari (K-G) Basin, Bay of Bengal (Fig. 1). Recently, paleo-cold seepage associated authigenic carbonate and chemosynthetic clam (Calyptogena sp.) shells have been reported from this site (Mazumdar et al., 2009b and 2011) and nearby site NGHP-10D (Collett et al., 2008). Based on ${ }^{14} \mathrm{C}$ and $\mathrm{U} / \mathrm{Th}$ age dating of foraminiferal tests and authigenic carbonates respectively, a minimum age of 46 to $58 \mathrm{kyr}$ was suggested for the methane expulsion events (Mazumdar et al., 2009).

In this work we have investigated the possible influence of methane emission on carbon isotope ratio of planktic and benthic foraminifera and further constrained the ages of the major methane expulsion events. We have also discussed the significance of shale tectonics as a possible mechanism to trigger methane release from the sediments of K-G basin. Additional evidence of shale tectonics induced methane expulsion and authigenic carbonate precipitation are presented from another coring location (MD161-15) in K-G basin. Our study locations lie within the continental slope region of eastern India (Fig. 1).

\section{Geological Setting}

The Krishna-Godavari basin is a passive margin, pericratonic rift basin located in the central part of the eastern continental margin of India, covering an area of $28,000 \mathrm{~km}^{2}$ on land and $145,000 \mathrm{~km}^{2}$ offshore. It has a maximum sediment thickness of $\sim 8 \mathrm{~km}$ in the offshore region. The Krishna and Godavari rivers supply the bulk of the detrital sediments in to the basin. Smectite bearing Godavari Clay Formation constitutes the Holocene-Pleistocene deposit of the K-G basin (Rao, 2001). The seismic reflection data off K-G basin (Collett et al., 2008; Dewangan et al., 2010; Shankar and Riedel, 2010) 
show regional presence of gas hydrates manifested in the form of bottom simulating reflectors (BSR) observed at depth of $125 \mathrm{mbsf}$ (water depth: 945m) to $220 \mathrm{mbsf}$ (water depth $1146 \mathrm{~m}$ ). BSRs represent a phase boundary, where the low-velocity, gas-charged sediments occur below the high-velocity gas hydrate bearing sediments (Singh and Minshull, 1993). Ramana et al. (2007) and Dewangan et al. (2010) have reported various shale tectonics induced structures like bathymetric mounds, deep seated shale diapirs and toe thrust faults from the K-G basin. Both coring sites (MD161-8 and 15) are located on the top of bathymetric mounds. These bathymetric mounds are commonly associated with fluid/gas migration features and show numerous fault systems which facilitate the flow and accumulation of gas hydrate (Dewangan et al., 2011).

\section{Methods}

Two piston cores of lengths $30 \mathrm{~m}\left(\mathrm{MD} 161-8\right.$ : Lat. $=15^{\circ} 51.8624^{\prime} \mathrm{N}$ and Long. $\left.=81^{\circ} 50.0692^{\prime} \mathrm{E}\right)$ and $31 \mathrm{~m}$ (MD161-15: Lat. $=16^{\circ} 00.5700^{\prime} \mathrm{N}$ and Long. $\left.=82^{\circ} 03.4502^{\prime} \mathrm{E}\right)$ were collected on-board Marion Dufresne (MD-161: May, 2007) using a Giant Calypso piston corer at water depths of 1033 and 983m respectively (Fig. 1). Close to the site MD161-8, sea water temperature and salinity profiles (Suppl. Figure-1) were generated using CTD system SBE 911plus (Seabird electronics 1td. USA). SEASOFT software modules have been used to calibrate and process the data from various sensors. The BGHSZ is calculated using an excel program based on linear approximation of the Maekawa et al. (1995) polynomial equation for $\mathrm{CH}_{4}$ hydrate P-T stability in water of $3.5 \% \mathrm{NaCl}$ salinity (Tim Collett, personal correspondence). A geothermal gradient of $44^{\circ} \mathrm{C} / \mathrm{km}$ has been reported by Collett et al.(2008) for the NGHP site 10D near to our coring location (MD161-8) in the K-G basin.

Gamma density (wet bulk density) of the whole cores was measured on board using a GEOTEK Multisensor Core Logger (MSCL) following standard GEOTEK calibration and measurement protocol. Assuming that the sediment is fully saturated with water and the grain and fluid densities are known, the porosity $(\phi)$, wet bulk density $\left(\rho_{\text {MSCL }}\right)$, grain density $\left(\rho_{s}=2.65 \mathrm{~g} / \mathrm{cc}\right)$ and fluid density $\left(\rho_{f l}=1.03 \mathrm{~g} / \mathrm{cc}\right)$ can be linked by equation-1. Porosity data is from Mazumdar et al.(2009)

$$
\left.\rho_{M S C L}=\phi \rho_{f l}+(1-\phi) \rho_{s} \quad \text { (Eq. } 1\right)
$$

Grain size analyses was carried out using a Microtrac Tri-Laser S3500 laser particle size analyzer of Metrohm. It uses $780 \mathrm{~nm}$ laser beams and has an assembly of 151 detector arranged in 0.02 
to $163^{\circ}$ curve. Prior to sampling, the sediment samples were desalinated and subsequently decarbonated using dilute $\mathrm{HCl}(1 \mathrm{~N})$. Organic carbon was removed by $10 \% \mathrm{v} / \mathrm{v} \mathrm{H}_{2} \mathrm{O}_{2}$. Na-hexametaphosphate was added to the final suspension to ensure decoagulation in the flow path of the suspension. Online ultrasonication was used in the particle flow path. The grain size values are reported as volume \%.

Dried and weighed aliquots of the sediment samples (MD161-8) were suspended in distilled water and gently sieved through $63 \mu \mathrm{m}$ mesh sieve. Approximately 10 to 15 clean tests of Globigerinoides ruber (G. ruber: planktic) and Uvigerina sp. (benthic) with the size ranging from 250$355 \mu \mathrm{m}$ were picked from the oven dried $>63 \mu \mathrm{m}$ fraction for oxygen and carbon stable isotope ratio measurement. Prior to the analyses, the foraminiferal tests were broken, cleaned in 5-10\% $\mathrm{H}_{2} \mathrm{O}_{2}$ and followed by ultrasonication in distilled water and methanol to remove contaminants. An aliquot from each sample was examined under scanning electron microscope (JEOL JSM-5800LV) for signs of dissolution and recrystallization. The images are taken in both normal and backscatter mode. Samples for oxygen and carbon stable isotope ratios were analyzed in a Kiel III carbonate preparation device interfaced with a Finnigan-MAT 252 isotope ratio mass spectrometer at the Department of Geological Sciences, University of Florida. This is a dual inlet system having a precision of $0.04 \%$ VPDB for $\delta^{13} \mathrm{C}$ and $0.08 \%$ VPDB for $\delta^{18} \mathrm{O}$ for calcite standard NBS- 19 .

Carbon isotope measurement of total organic carbon were carried out using a Thermo-Finnigan Delta-V-Plus continuous flow isotope ratio mass spectrometer attached to an elemental analyzer (Thermo EA1112). The external precision calculated for $\delta^{13} \mathrm{C}$ is typically $0.07-0.09 \%$ (VPDB). Carbon isotope ratios are reported in standard format relative to VPDB standard. Total inorganic carbon (TIC) content was determined by carbon coulometer (UIC-CM5130). Total carbon (TC) content was measured by elemental analyzer (Thermo EA1112). Total organic carbon (TOC) was calculated by subtracting TIC from TC. Ultrapure $\mathrm{CaCO}_{3}$ (Sigma-Aldrich) was used as standard for TIC measurement. Precision for TC and TIC measurements are 1 and $1.4 \%$ respectively.

AMS ${ }^{14} \mathrm{C}$ dates for one core (MD161-15) were generated at the National Ocean Sciences AMS (NOSAMS) facility, Woods Hole Oceanographic Institution, USA. Dates were determined on planktic foraminifera. Carbon dioxide generated from these foraminifera shells was reacted with catalyst to form graphite which was pressed into targets and analyzed on the accelerator along with standards and 
process blanks. Two primary standards used during ${ }^{14} \mathrm{C}$ measurements are NBS Oxalic Acid I (NISTSRM-4990) and Oxalic Acid II (NIST-SRM-4990C).

Authigenic carbonate precipitates and shell fragments in MD161-15 were isolated, cleaned and photographed. Mineralogical identification was carried out using a Rigaku X-ray diffractometer (Ultima-IV). All the carbonate samples were run from 25 to $32^{\circ} 2 \theta$ at $1 \%$ min scan speed using $\mathrm{CuK}_{\alpha}$ radiation $(\lambda=1.541838 \AA)$. The $\mathrm{MgCO}_{3}\left(\right.$ mole \%) was calculated using a $\mathrm{MgCO}_{3}$ (mole \%) d-spacing standard curve in Hardy and Tucker (1988). Carbon and oxygen isotope ratios of four authigenic carbonate samples from MD161-15 were determined with a Thermo Delta V continuous flow isotope ratio mass spectrometer attached with a GASBENCH II and equipped with a PAL auto sampler at the National Geophysical Research Institute, Hyderabad, India. The carbon isotope ratios are reported in standard $\delta^{13} \mathrm{C}$ and $\delta^{18} \mathrm{O}$ format relative to VPDB standard. A sample reproducibility of $0.1 \%$ for both carbon and oxygen is reported here.

For total lipid extraction, 15g of freeze dried and pulverized sediment aliquots from MD161-8 were extracted with a mixture of $\mathrm{CH}_{2} \mathrm{Cl}_{2}: \mathrm{CH}_{3} \mathrm{OH}(1: 1, \mathrm{vv})$ three times using ultrasonication for 15 minutes. Extracts were desulfurized with activated copper and vacuum evaporated to near dryness, and hydrolyzed (saponification) overnight with $15 \mathrm{ml}$ of $10 \% \mathrm{KOH}$ in methanol. Non-saponifiable compounds were recovered with hexane/diethyl ether (9:1) mixture (4X20ml). The resultant extract is concentrated to $1 \mathrm{ml}$ and eluted through a liquid chromatography column $(20 \mathrm{X} 0.8 \mathrm{~cm})$ filled with $4.2 \mathrm{~g}$ of silica gel (60-120 mesh) deactivated with $5 \%$ water by weight. The three fractions, namely aliphatic hydrocarbons, aromatic and alcohols, were eluted sequentially with the $40 \mathrm{ml}$-hexane, $32 \mathrm{ml}$-hexane plus $8 \mathrm{ml}$ toluene and $32 \mathrm{ml}$-hexane plus $8 \mathrm{ml}$ ethyl acetate respectively. The aliphatic fractions were reduced to $800 \mu \mathrm{l}$ for GC/MS analysis. Perduterated Docosane $\left(\mathrm{C}_{12} \mathrm{D}_{26}, 0.8 \mu \mathrm{g}\right)$ was added as an internal standard. GC-MS was performed using a Shimadzu QP-2010 gas chromatograph interfaced with a QP2010 mass spectrometer. The gas chromatograph is equipped with a $30 \mathrm{~m}$ long Rtx-5 MS capillary column from Restek, USA.

Compound specific $\delta^{13} \mathrm{C}$ values of the aliphatic hydrocarbon fraction were determined using a Thermo delta V plus isotope ratio mass spectrometer coupled with a Thermo Trace GC. A DB5 (length: $30 \mathrm{~m}$, ID $=0.25 \mathrm{~mm}$, film thickness $=0.25 \mu \mathrm{m})$ column was used for chromatographic separation of compounds. Separated compounds are sequentially carried by the helium into the GC combustion unit at 
$980^{\circ} \mathrm{C} . \mathrm{CO}_{2}$ produced through combustion is subjected to isotope ratio measurement. $\delta^{13} \mathrm{C}$ values are given in permil (\%) relative to the Vienna Peedee Belemenite (VPDB) standard.

\section{Results}

\subsection{Base of hydrate stability zone}

The bottom water temperature at a water depth of $1033 \mathrm{~m}$ in $\mathrm{MD} 161-8$ site is $6.6^{\circ} \mathrm{C}$. The calculated BGHSZ for the site MD161-8 based on the estimated geothermal gradient of $44^{\circ} \mathrm{C} / \mathrm{km}$ is $\sim 150$ mbsf which is close to the observed depth of BSR ( 160 mbsf; Collett et al., 2008).

\subsection{Grain size distribution}

Silt and clay constitute bulk of the sediments (Fig. 2). Silt and clay concentrations in MD161-8 are $24-54 \mathrm{vol} \%$ and $45-73 \mathrm{vol} \%$ respectively. Relatively high sand concentration (1.8 to $5.5 \mathrm{vol} \%$ ) is measured within the depth zone of 811 to $1389 \mathrm{cmbsf}$. In MD161-15, the silt and clay concentrations are $24-58 \mathrm{vol} \%$ and $26-74 \mathrm{vol} \%$ respectively. Sand is present as a minor components ( $<10 \mathrm{vol} \%)$ except in few samples within 700-800 mbsf in MD161-15 where maximum sand concentration range from 16 to $31 \mathrm{vol} \%$.

\subsection{Foraminifera microstructure}

Scanning Electron Microscopic studies (Fig. 3 A-F) of foraminifera tests screened for the $\mathrm{C}$ and $\mathrm{O}$ isotope analyses show pristine preservation with no evidence of recrystallization or shell dissolution. Pores are open (Fig. 3 B, D) and free of any secondary crystalline fillings. Shells show clear growth layers and knobs. In few specimens intact spines are recorded (Fig. 3C), suggesting excellent preservation of original micro/ultrastructures. Figures $3 \mathrm{E}$ and $\mathrm{F}$ show smooth surfaces in between the ridges. Lack of infilling in broken shells suggest good preservation of original shell composition.

\subsection{Age-depth model}

The age-depth model for MD161-8 (Fig. 4) is based on the calibrated radiocarbon ages (Mazumdar et al., 2009) and correlation of our $\delta^{18} \mathrm{O}$ profile with the standard $\delta^{18} \mathrm{O}$ profile of G. ruber from the northern Bay of Bengal (Kudrass et al., 2001). Five marine isotope stages (MIS 5 to 1) 
representing glacial and interglacial changes are demarcated in figure 4. The time windows for the Last Glacial maxima (LGM), Bølling-Allerød interstadial (B/A) and Younger Dryas (Y-D) events are demarcated in figure-4. Some of the Dansgaard-Oeschger events (D-O events) correlatable with Kudrass et al. (2001) are plotted in the figure. The age depth model of MD161-15 (Fig. 5) shows markedly high sedimentation rate $(53.4$ to $319.7 \mathrm{~cm} / \mathrm{ky})$ in the upper 9 mbsf. Below the sedimentation rate range from 7.2 to $27.5 \mathrm{~cm} / \mathrm{ky}$.

$4.5 \delta^{13} \mathrm{C}-\delta^{18} \mathrm{O}$ values

Negative $\delta^{13} \mathrm{C}$ excursions, $\mathrm{P}_{1}$ to $\mathrm{P}_{6}$ (Fig. 6B) and $\mathrm{B}_{1}$ to $\mathrm{B}_{3}$ (Fig. 6D) are marked on the $\delta^{13} \mathrm{C}$ profiles of G. ruber and Uvigerina sp. respectively. $\mathrm{P}$ and B stand for planktic and benthic foraminifera respectively (Suppl. Table- 1 and 2). Several minor $\mathrm{C}$ isotopic excursions can be seen between $\mathrm{P}_{4}-\mathrm{P}_{6} . \mathrm{P}_{4}$ to $\mathrm{P}_{6}$ and $\mathrm{B}_{1}$ to $\mathrm{B}_{3}$ show similar relative intensity pattern. Peaks equivalent to $\mathrm{P} 1$ to $\mathrm{P} 3$ are not recorded in the benthic foraminifera profile. The $\delta^{13} \mathrm{C}-\delta^{18} \mathrm{O}$ cross plots for benthic and planktic foraminifera along with authigenic carbonates (Mazumdar et al., 2009) are presented in figure-7A and C. Figure 7B and D represent the cross plots of $\delta^{13} \mathrm{C}$ and $\delta^{18} \mathrm{O}$ data points within the time windows 60208-78508 y (Uvigerina sp.) and 59720-78264 y (G.ruber) respectively. The C-O isotope profiles within this time window is zoomed in Supplemenatry figure 2. No significant correlation is observed in either plots.

\subsection{Authigenic carbonate and Clam shells.}

Tubular and massive carbonate bodies are the dominant authigenic carbonate types recovered from MD161-15 (Fig. 8). Well preserved Scaphopoda shells (benthic burrowing mollusc) are observed cemented on the carbonate structures. Fragments of chemosynthetic clam shells (Calyptogena sp. and Lucinoma sp.) recovered within the depth range of 27 to $31 \mathrm{mbsf}$ are presented in figure-9. $\delta^{13} \mathrm{C}$ values of four representative carbonate samples are $-46.8,-47.3,-47.9$ and $-50.2 \%$ VPDB (Suppl. Table- 3 ).

\subsection{TIC and Organic geochemistry}

TIC concentrations range from 0.11 to $2.2 \mathrm{wt} \%$ and show marked vertical fluctuation (Fig. 10A). The $\delta^{13} \mathrm{C}_{\text {TIC }}$ data in figure-10A is from Peketi et al. (2012). The total organic carbon contents (Suppl. Table- 4) in MD161-8 varies from 1.1 to $2 \mathrm{wt} \%$ (Fig.10B). The TOC/TN ratio in MD161-8 range from 10.4 to 30.6 (avg: $16.1 \pm 3.5$ ). $\quad \delta^{13} \mathrm{C}_{\text {TOC }}$ profile (Fig. 6E, Suppl. Table-4) shows marked negative 
excursion during MIS-4 relative to the average value of $-17.0 \pm 1.8 \%$ VPDB. The aliphatic hydrocarbon extracts from the sediment samples within this zone show the presence of 2,6,10,15,19pentamethylicosane (PMI: Fig. 11). PMI could be quantified only in two samples within the depth zone of 16-18 mbsf. Quantification of PMI was done relative to the internal standard. PMI concentration ranges from 0.34 to $0.75 \mu \mathrm{g} / \mathrm{g}$ of dry sediment. $\delta^{13} \mathrm{C}_{\mathrm{PMI}}$ values of two samples reported here are -107 and $-139 \%$ VPDB (Fig. 6E).

\section{Discussion}

\subsection{C-O isotopic perturbation: Possible diagenetic influence}

Recrystallization of foraminifera shell or precipitation of ${ }^{13} \mathrm{C}$ depleted authigenic carbonate crystals within the shell cavities are the commonly cited causes for highly negative $\delta^{13} \mathrm{C}$ signature of foraminifera shells (Martin et al., 2004; Ohkushi et al., 2005; Wiedicke and Weiss, 2006; Uchida et al, 2008; Torres et al., 2010 and Cook et al., 2011). The shells analysed (Fig. 3) in our study are not brown or yellowish in colour and also do not show any apparent recrystallization features under scanning electron microscope (SEM). In fact, the structures are extremely well preserved (Fig. 3). We also have not observed any authigenic carbonate fillings within the pores or inside the cavities. However, some minute remnants are very difficult to ascertain unless every individual shells analysed for isotopic composition is observed under SEM. In figure-7 A and C no obvious mixing line could be established between the authigenic carbonate and foraminifera data clusters unlike the observation by Wiedicke and Weiss, (2006) from Sunda arc basin. Inclusions of authigenic carbonates with $\delta^{18} \mathrm{O}$ values ranging from +3.2 to $+5.2 \%$ VPDB (Fig. 7A and C) would result in ${ }^{18} \mathrm{O}$ enrichment in foraminifera shell and a positive shift in $\delta^{18} \mathrm{O}$ relative to the pristine shells. The effect of contamination with ${ }^{18} \mathrm{O}$ enriched authigneic carbonate is expected to be more prominent in planktonic than benthic foraminifera since benthic forms during MIS-4 are reported to be enriched in ${ }^{18} \mathrm{O}$ (Pitrowski et al., 2009). Figure 7B and D show the data cluster within the time window $60208-78508$ y when the most intense ${ }^{13} \mathrm{C}$ depletion is recorded. The data points show no notable correlation. However, the observed similarity of $\delta^{18} \mathrm{O}_{G . r u b e r}$ values during MIS-4 and MIS-2 (Fig. 6B) in MD161-8 is contrasting to the observation of Kudrass et al. (2001) from the Bay of Bengal (Fig. 4A). This possibly suggest incorporation of ${ }^{18} \mathrm{O}$ enriched carbonate in the foraminifera at the site (MD161-8). The ${ }^{18} \mathrm{O}$ enrichment may be attributed to the post depositional diagenetic alteration which is not detected by normal visual inspection. The $\delta^{18} \mathrm{O}$ values 
possibly resulted by ${ }^{18} \mathrm{O}$ enriched water released during the destabilization of methane hydrate (Matsumoto and Borowski, 2000) or inclusion of undetected ${ }^{18} \mathrm{O}$ enriched authigenic carbonate. Rigorous chemical analyses like $\mathrm{Mg} / \mathrm{Ca}, \mathrm{Mn} / \mathrm{Ca}$ ratios and $\Delta^{14} \mathrm{C}$ is required to narow down the least contaminated shells (Uchida et al., 2008). ${ }^{87} \mathrm{Sr} /{ }^{86} \mathrm{Sr}$ ratio may also help in understanding the sediment porefluid calcite shell interaction. Incorporation of ${ }^{13} \mathrm{C}$ depleted dissolved inorganic carbon (DIC) produced solely via degradation of organic rain cannot explain the repeated spikes in ${ }^{13} \mathrm{C}$ depletion (Stott et al., 2002) in the C- isotope ratio profiles (Fig. 6 B and D) since the TOC content varies within a narrow band (Avg: $1.5 \pm 0.2 \mathrm{wt} \%$; Fig. 10B ) in MD161-8 and does not show any high concentration spikes correlatble with the planktic or benthic $\mathrm{C}$-isotopic depletions.

Based on the present observation we cannot rule out the role of diagenetic processes in partially altering the carbon-oxygen stable isotope ratios of the measured foraminifera. However, the lack of visible recrystallization or incorporation of authigenic carbonates fail to provide a comprehensive explanation for the observed episodic isotopic perturbations only through diagenesis, thus leaving the room for at least partial contribution of palaeocenographic processes as one of the possible causative factors as observed by Uchida et al. (2008).

\subsection{Methane emission and C isotope perturbation}

The negative carbon isotope excursions (Fig. 6B and D) corresponding to $\mathrm{P}_{1}, \mathrm{P}_{2}$ and $\mathrm{P}_{3}$ are not observed in the benthic foraminifera. In other words the processes responsible for changing the carbon isotope ratios of the shallow water bicarbonate reservoir during $\mathrm{P}_{1}, \mathrm{P}_{2}$ and $\mathrm{P}_{3}$ events were apparently decoupled from the deep water bicarbonate pool. Timings of $\mathrm{P}_{2}$ and $\mathrm{P}_{3}$ may correspond to the Dansgaard-Oeschger warming events during the 40-50 ky time window (Kudrass et al., 2001). However, it is difficult to relate the observed small carbon isotope perturbation to episodic destabilization of methane hydrate deposits (Kennett et al., 2000; Kennett et al., 2003) of K-G basin in the absence of corresponding ${ }^{13} \mathrm{C}$ depletion in benthic foraminifera and other biological/ geochemical evidence (Mazumdar et al., 2009b). Wetland methane emission could also have influenced the depleted carbon isotopic signature. The negative $\delta^{13} \mathrm{C}$ excursion, $\mathrm{P}_{1}$ at the LGM, may also be attributed to the upwelling of Southern Ocean deep water with depleted carbon stable isotope ratios (Spero and Lea, 2002) in-to the shallow waters of Northern Indian Ocean during deglaciation. The planktic foraminifera G.ruber also show negative carbon isotopic excursions (P4, P5 and P6) which are stratigraphically close to the 
excursion B1, B2 and B3. Compared to the benthic foraminifera, the planktic counterpart shows several excursions close to P4, P5 and P6. A palaeocenographic explanation for the ${ }^{13} \mathrm{C}$ depleted planktic foraminifera would involve carbon isotopic alteration of the bicarbonate reservoir of the upper mixed layer $(0-25 \mathrm{~m})$ by the aerobic oxidation of the methane expelled from the sediment bed (Blumenberg et al., 2007). The volume of methane gas that can reach the shallow waters depends on several factors. Model calculations by Zhang (2003) and Leifer et al. (2006) show that the efficiency of methane ebullition depends on the water depth, magnitude of seepage, upward velocity, bubble size and presence of hydrate coating on methane bubbles (Sauter et al., 2006). However, a direct link between the negative carbon isotopic excursion observed in G. ruber and methane flux into the shallow waters is not possible to establish unequivocally in the present work due to the regional nature of the event and possibility partial diagenetic alterations.

The pulses of depleted carbon isotope excursions in benthic $\left(\mathrm{B}_{1}, \mathrm{~B}_{2}\right.$ and $\left.\mathrm{B}_{3}\right)$ foraminifera possibly suggest that the methane expulsion events during MIS-4 (Glacial stage) and at the transition of MIS-4 and MIS-5 (interglacial), altered the bicarbonate carbon isotopic composition near the sediment water interface (Wefer et al., 1994; Panieri et al., 2012; Wang et al., 2013). A significant fraction of methane is oxidized to $\mathrm{HCO}_{3}{ }^{-}$via anaerobic methane oxidation (AMO) close to the sediment water interface. AMO is attributed to a consortium of $\mathrm{CH}_{4}$-oxidizing archaea and sulfate-reducing bacteria (Orphan et al., 2001; Reeburgh, 2007; Knittel and Boetius, 2009) and can be represented by equation 1.

$$
\mathrm{CH}_{4}+\mathrm{SO}_{4}{ }^{2-} \rightarrow \mathrm{HCO}_{3}^{-}+\mathrm{HS}^{-}+\mathrm{H}_{2} \mathrm{O}
$$

Presence of chemosythetic bivalves like Calyptogena sp (Collett et al.,, 2008; Mazumdar et al., 2009b) and of Mo concentration anomaly within 16-18 mbsf (depth zone of foraminifera carbon isotope anomaly) of core MD161-8 (Peketi et al., 2012), have convincingly demonstrated paleo methane expulsion events and accompanied AMO/ sulfidization at or above the sediment water interface in $\mathrm{K}-\mathrm{G}$ basin. On the other hand extensive studies on long sediment cores collected from K-G basin, Mazumdar et al.(2012) have shown evidence of recent as well as paleo vertical movement of the sulfate- methane transition zones in the K-G basin due to variations in the methane flux possibly driven by activation of fault system.

Depletion in carbon isotope ratios of the dissolved inorganic carbonate (DIC) pool depends on the carbon stable isotope ratios of methane advecting from the deeper sediment layers. Reported 
$\delta^{13} \mathrm{C}_{\mathrm{CH} 4}$ values (-75 to $-85 \%$ VPDB) and $\mathrm{C} 1 /(\mathrm{C} 2+\mathrm{C} 3)$ ratios (1110 to 3354$)$ by Collett et al., 2008 and Mazumdar et al., 2009b and 2012) suggest the presence of biogenic hydrocarbon gases within the methanogenic zone at the site MD161-8. Carbon isotope values of shallow (top $\sim 0.5 \mathrm{cmbsf}$ ) infaunal benthic foraminifera such as Uvigerina sp. may get significantly influenced by incorporation of bicarbonate with isotopically depleted carbon in the calcitic shell during growth (Hill et al., 2003 and 2004b). Carbon isotopic composition of benthic foraminifera may also be influenced by the carbon isotope ratios of food source (Panieri et al., 2009). The presence of 2,6,10,15,19-pentamethylicosane (PMI) an archaeal membrane lipid biomarker with extremely depleted carbon isotope ratios (-106 to $139 \%$ VPDB) suggest AOM and enhanced abundances of methanotrophic archaeal biomass governed by methane emission (Orphan et al., 2001; Thiel et al., 2001; Peckmann and Thiel, 2004; Zhiguang and Wang, 2006). Niemann et al. (2006) reported PMI from methane seepage related carbonate crust from gulf of Cadiz mud volcano. The free energy yield $\left(-25 \mathrm{~kJ} \mathrm{~mol}^{-1}\right)$, ANME cell count $\left(<10^{6} \mathrm{cells} \mathrm{cm}^{-3}\right)$ and AOM rate $\left(<10 \mathrm{nmol} \mathrm{cm}^{-3} \mathrm{day}^{-1}\right)$ reported from the deep SMTZ below seafloor are lower, compared to those from seep/ vent sites (Valentine and Reeburgh, 2000; Valentine, 2002; Knab et al., 2008; Harrison et al., 2009; Knittel and Boetius, 2009). The sharp negative excursion in the bulk $\delta^{13} \mathrm{C}_{\text {TOC }}$ (Fig. 6E) within 16-18 mbsf possibly reflect the incorporation of isotopically depleted archaeal biomass in the sediment. Lack of correlatable change in TOC/TN ratio with the $\delta^{13} \mathrm{C}_{\mathrm{TOC}}$ spikes rules out high marine productivity as a reason for the ${ }^{12} \mathrm{C}$ enriched TOC. Benthic foraminifera feeding on such microbial mats may grow tests with markedly depleted carbon isotope ratios (Sen Gupta et al., 1997; Levin and Michener, 2002). Depleted carbon isotope ratios in benthic foraminifera are considered as a potential proxy for paleo-methane seepage (Wefer et al., 1994; Kennett et al., 1996; Sen Gupta et al., 1997; Rathburn et al., 2000). However, the interpretation of seepage indicator need more detailed investigation since PMI has also been reported from SMTZ deeper within the sediment (Lee et al., 2013, Weijers et al., 2011; Aquilina et al., 2010).

\subsection{Gas hydrate destabilzation: Tectonics and perturbed P-T condition}

Thermodynamic calculations based on hydrate stability equations (Sloan, 1998) show that the present base of the gas hydrate stability zone (BGHSZ) in offshore K-G basin is $\sim 150$ mbsf which is close the depth of BSR ( $\sim 160 \mathrm{mbsf})$. Bright spots, acoustic blanking/turbidity and drop in P-wave velocity below BSR testify the presence of free gas (Dewangan et al., 2010; Shankar and Riedel, 2010). Based on the enrichment in the oxygen isotope and $\mathrm{Mg} / \mathrm{Ca}$ ratios in benthic foraminifera (Martin et al., 
2002; Waelbroeck et al., 2002), temperature drop (relative to present) of $\sim 2$ and $3^{\circ} \mathrm{C}$ can be estimated for the deep waters of the equatorial/tropical pacific and southern Indian oceans respectively during MIS-4. Since no bottom water temperature estimation is available for the late Quaternary from northern Indian Ocean, we assume that the bottom water temperature during MIS 4 was at least 1-2 degree lower than that of the present $\left(6.6^{\circ} \mathrm{C}\right)$ at our sampling depth. Based on SPECMAP data, the estimated sea level was $\sim 90$ to 95 m below present during the MIS-4 and at the transition of MIS-5 to MIS-4 (Berné et al., 2004). Calculations using different combination of P-T conditions show that BGHSZ was possibly deeper by $\sim 10$ to $36 \mathrm{~m}$ relative to the present depth of BGHSZ ( $\sim 150 \mathrm{mbsf})$ thus increasing the methane hydrate stability zone. Moreover, the record of benthic foraminifera $\delta^{18} \mathrm{O}$ pattern (Fig. $6 \mathrm{C}$ ) does not support rapid or episodic bottom water warming corresponding to the depleted carbon isotopic excursions (Fig. 6D). However, assuming no reduction in bottom water temperature relative to the present, a S.L drop of 90-95 m would destabilize the methane hydrate and push the BGSHZ upward by $\sim 16 \mathrm{~m}$. This would result in the generation of free gas which may emit out of the sea bed if conduits are available. However, in either case, conduits in the form of fault systems requires passive tectonics processes typically associated with shale tectonism in K-G basin. Sustaining flow of methane gas through conduits across the hydrate stability zone has to be facilitated by additional physicochemical conditions like warm fluid or enhanced salinity to avoid hydrate crystalization.

Shale tectonics (diapirism) induced deep fault system has been amply demonstrated from the KG Basin (Mazumdar et al., 2009b; Dewangan et al., 2010; Shankar and Riedel, 2010; Riedel et al., 2010; Choudhury et al.,2011). Shale tectonic is driven by the downward movement of thick sediment mass over a deeply buried over pressured shale strata (Damuth, 1994; Wu and Bally, 2000). The perturbation of the over pressured strata induces folding, faulting and upthrusting of the overburden strata thereby creating prominent bathymetric mounds and ridges (Rao and Mani, 1993; Dewangan et al.,2010). Migration through the deep fault systems possibly played an important role in advection of the fluids (Shankar and Riedel, 2010; Dewangan et al., 2011; Jaiswal et al., 2012). Fluids advecting from greater depths are likely to be much warmer than the shallow sediments in the GHSZ (Max et al., 2006). The increase in geothermal gradient (calculated using BSR) in the vicinity of the studied core (Dewangan et al., 2011) suggest advection of warm fluid through the contemporaneous fault systems resulting in focused fluid flow (Carson and Screaton, 1998). The episodic nature of the carbon isotopic excursions (Fig. 6B and D) suggests periodic quiescence or reactivation of fault system. This association in K-G basin is further supported by the record of paleo- methane seepage related authigenic carbonate deposits 
at the site MD161-15. The wet bulk density (Dewangan et al., 2010) of the core MD161-15 also shows the occurrences of lithified authigenic carbonates within a depth zone of 27 to $31 \mathrm{mbsf}$ (Fig. 5D). The tubular shaped carbonate structures (Fig. 10) with strong depletion in carbon isotope ratios (Table TS 5) and presence of fossil shells of shallow surface dwelling or burrowing mollusk (Scaphopoda) suggest near surface precipitation of high magnesian carbonates at MD161-15 due to methane emission and anaerobic oxidation of methane (Suppl. Table -3). Methane expulsion is further supported by the record of chemosynthetic clam shells (Calyptogena and Lucinoma sp.) from the authigenic carbonate rich horizons (Fig. 11). Earlier Mazumdar et al. (2009) reported these type of clam shells from core MD1618. The timing of this methane seepage event recorded in MD 161-15 is yet to be determined. Like MD161-8, the coring site MD161-15 is also located on a shale tectonics induced mound overlying a gas hydrate deposit. Evidence from of methane emission events from the two sites located on mounds in K-G basin supports the link between passive tectonics induced fault/ and methane emission events in KG basin.

\section{Conclusions}

We have recorded negative spikes $\left(\mathrm{P}_{4}-\mathrm{P}_{6}\right.$ and $\left.\mathrm{B}_{1}-\mathrm{B}_{3}\right)$ of carbon isotope ratios in the planktic $(G$. ruber) and benthic (Uvigerina sp.) foraminifera within MIS-4 and at the transition of MIS-5 and 4 which can be correlated with methane expulsion events in K-G basin, Bay of Bengal. The influence of diagenetic modification on the isotopic signals can not be ruled out in the present study. The negative excursions observed in benthic foraminifera are significantly larger than in the planktic counterpart. The carbon isotopic perturbations in the foraminifera in MD161-8 can be correlated with the earlier reports on occurrence of chemosythetic bivalve fossils and positive Mo anomaly within same time window. The above observations have attributed to methane emmision event likely caused by methane hydrate destabilzation. The hydrate destabilization and methane emission event in K-G basin has been linked to shale tectonic events leading to fracture and fault generation which provided the vertical conduit for the emission of methane gas. We suggest that the globally recorded shale and salt tectonics and associated focused fluid flow in passive continental margins play an important role in marine methane seepage events. 


\section{Acknowledgements}

We thank the directors of CSIR-NIO, NIOT, NCAOR and advisor MOES for supporting this study. Head, oceanography department, and in-charge on-board operations of IPEV are thanked for providing onboard technical support and facilities. Funding support to RJ and AP from CSIR and VNJCT are sincerely acknowledged. Mr. G. Prabhu and Mr. V.D. Khedekar/A. Sardar helped in acquiring XRD and SEM data at NIO respectively.

\section{References:}

Aquilina, A., Knab, N. J., Knittel, K., Kaur, G., Geissler, A., Kelly, S. P., Fossing, H., Boot, C. S., Parkes, R. J., Mills, R. A., Boetius, A., Lloyd, J. R., Pancost, R. D., 2010. Biomarker indicators for anaerobic oxidizers of methane in brackish-marine sediments with diffusive methane fluxes. Organic Geochemistry, 41, 414-426.

Archer, D., 2007. Methane hydrate stability and anthropogenic climate change. Biogeosciences Discussions 4, 993-1057.

Berné, S., Rabineau, M., Flores, J.A., Sierro, F.J., 2004. The impact of Quaternary global changes on strata formation: exploration of the shelf edge in the Northwest Mediterranean Sea. Oceanography 17, 92-103.

Blumenberg, M., Seifert, R., Michaelis, W., 2007. Aerobic methanotrophy in the oxic-anoxic transition zone of the Black Sea water column., Org. Geochem. 38, 84-91.

Bock, M., Schmitt, J., Möller, L., Spahni, R., Blunier, T., Fischer, H., 2010. Hydrogen isotopes preclude marine hydrate $\mathrm{CH}_{4}$ emissions at the onset of Dansgaard-Oeschger events. Science 328, 16861689.

Buffett, B., Archer, D., 2004. Global inventory of methane clathrate: sensitivity to changes in the deep ocean. Earth Planet. Sci. Lett. 227, 185-199.

Carson, B., Screaton, E.J., 1998. Fluid flow in accretionary prisms: Evidence for focused, timevariable discharge. Rev. of Geophys. 36, 329-351.

Chanton, J.P., Whiting, G.J., 1996. Methane stable isotopic distributions as indicators of gas transport mechanisms in emergent aquatic plants. Aqu. Botany 54, 227-236.

Chappellaz, J., Blunier, T., Kints, S., Dallenbach, A., Barnola, J.M., Schwander, J., Raynaud, D., Stauffer, B., 1997. Changes in the atmospheric $\mathrm{CH}_{4}$ gradient between Greenland and Antarctica during the Holocene. J. Geophys. Res. Atmosph. 102, 15987-15997.

Choudhori, M., Guha, D., Dutta, A., Sinha, S., and Sinha, N., 2011. Spatiotemporal Variations and Kinematics of Shale Mobility in the Krishna-Godavari Basin, India. In AAPG Memoir 93 Shale 
Tectonics, Ed. Wood, L.H., pp. 91-110.

Coffin, R. B., Smith, J. P., Plummer, R. E., Yoza, B., Larsen, R. K., Millholand, L. C., Montomery, M. T., 2013. Spatial variation in shallow sediment methane source and cycling on the Alaskan Beaufort Sea shelf/ slope. Mar. Pet.Geol. 45, 186-197.

Collett, T., Riedel, M., Cochran, J., Boswell, R., Presley, J., Kumar, P., Sathe, A., Sethi, A., Lall, M., Sibal, V., 2008. National Gas Hydrate Program: Expedition 01, Initial Reports, vol. 1, Dir. Gen. of Hydrocarbon, New Delhi, India.

Cook, M.S., Keigwin, L.D., Birgel, D., Hinrichs, K.-U., 2011. Repeated pulses of vertical methane flux recorded in glacial sediments from the southeast Bering Sea. Paleoceanography 26, 1-17.

Dällenbach, A., Blunier, T., Fluckiger, J., Stauffer, B., Chappellaz, J., Raynaud, D., 2000. Changes in the atmospheric $\mathrm{CH} 4$ gradient between Greenland and Antarctica during the Last Glacial and the transition to the Holocene. Geophys. Res. Lett. 27, 1005-1008.

Damuth, J.E., 1994. Neogene gravity tectonics and depositional processes on the deep Niger Delta continental margin. Mar. Pet. Geol. 11, 320-346.

De Garidel-Thoron, T., Beaufort, L., Bassinot, F., Henry, P., 2004. Evidence for large methane releases to the atmosphere from deep-sea gas-hydrate dissociation during the last glacial episode. Proceedings of the National Academy of Sciences of the United States of America 101, 9187-9192.

Dewangan, P., Ramprasad, T., Ramana, M., Mazumdar, A., Desa, M., Badesab, F.K., 2010. Seabed Morphology and Gas Venting Features in the Continental Slope Region of Krishna-Godavari Basin, Bay of Bengal: Implications in Gas-Hydrate Exploration. Mar. Pet. Geol. 27, 1628-1641.

Dewangan, P., Sriram,G., Ramprasad, T. Ramana, M., Jaiswal, P., 2011. Fault system and thermal regime in the vicinity of site NGHP-01-10, Krishna-Godavari basin, Bay of Bengal, Mar. Pet. Geol. 28, 1899-1914.

Dickens, G.R., 2003. Rethinking the global carbon cycle with a large, dynamic and microbially mediated gas hydrate capacitor. Earth Planet. Sci. Lett. 213, 169-183.

Dickens, G., O'Neil, J., Rea, D., Owen, R., 1995. Dissociation of oceanic methane hydrate as a cause of the carbon isotope excursion at the end of the Paleocene. Paleoceanography 10, 965-971.

Etiope, G., Lassey, K.R., Klusman, R.W., Boschi, E., 2008. Reappraisal of the fossil methane budget and related emission from geologic sources. Geophys. Res. Lett. 35, L09307.

Hardy, R., Tucker, M., 1988. X-ray powder diffraction of sediments. Techniques in Sedimentology, edited by, M. Tucker, pp 191-228, Blackwell Scientific Publication, Oxford, U.K.

Harrison, B.K., Zhang, H., Berelson, W., Orphan, V.J., 2009. Variations in archaeal and bacterial diversity associated with the sulfate-methane transition zone in continental margin sediments (Santa Barbara Basin, California). Applied and Environmental Microbiology 75, 1487-1499. 
Herguera, J. C., C. K. Paull, E. Perez, W. Ussler III, and E. Peltzer, 2014, Limits to the sensitivity of living benthic foraminifera to pore water carbon isotope anomalies in methane vent environments, Paleoceanography 29, 273-289.

Hill, T.M., Kennett, J.P., Spero, H.J., 2003. Foraminifera as indicators of methane-rich environments: A study of modern methane seeps in Santa Barbara Channel, California. Mar. Micropal. 49, 123-138.

Hill, T.M., Kennett, J.P., Spero, H.J., 2004a. High-resolution records of methane hydrate dissociation: ODP Site 893, Santa Barbara Basin. Earth Planet. Sci. 223, 127-140.

Hill, T.M., Kennett, J.P., Valentine, D.L., 2004b. Isotopic evidence for the incorporation of methane-derived carbon into foraminifera from modern methane seeps, Hydrate Ridge, Northeast Pacific. Geochim. Cosmochim. Acta 68, 4619-4627.

Hinrichs, K.U., Hmelo, L.R., Sylva, S.P., 2003. Molecular fossil record of elevated methane levels in late Pleistocene coastal waters. Science 299, 1214-1217.

Hovland, M., Judd, A.G., 1992. The global production of methane from shallow submarine sources. Continental Shelf Res. 12, 1231-1238.

Jahren, A.H., Arens, N.C., Sarmiento, G., Guerrero, J., Amundson, R., 2001. Terrestrial record of methane hydrate dissociation in the Early Cretaceous. Geology 29, 159-162.

Jaiswal, P., Dewangan, P., Ramprasad, T., Zelt, C.A., 2012. Seismic characterization of hydrates in faulted, fine-grained sediments of Krishna-Godavari basin: Unified imaging. J. Geophys. Res. 117, B10305.

Judd, A.G., Hovland, M., Dimitrov, L.I., Garcia Gil, S., Jukes, V., 2002. The geological methane budget at continental margins and its influence on climate change. Geofluids 2, 109-126.

Kaplan, J.O., 2002. Wetlands at the Last Glacial Maximum: Distribution and methane emissions. Geophys. Res. Lett. 29.

Kemp, D.B., Coe, A.L., Cohen, A.S., Schwark, L., 2005. Astronomical pacing of methane release in the Early Jurassic period. Nature 437, 396-399.

Kennedy, M., Mrofka, D., von der Borch, C., 2008. Snowball Earth termination by destabilization of equatorial permafrost methane clathrate. Nature 453, 642-645.

Kennett, J., Cannariato, K., Hendy, I., Behl, R., 2000. Carbon isotopic evidence for methane hydrate instability during Quaternary interstadials. Science 288, 128-133.

Kennett, J. P., Cannariato, K. G., Hendy, I. L., Behl, R. J., 2003. Methane hydrates in Quaternary climate change: The clathrate gun hypothesis. Amer Geophysical Union, 216 pp., Washington, DC.

Kennett, J.P., Stott, L.D., 1991. Abrupt deep sea warming, paleoceanographic changes and benthic extinctions at the end of the Paleocene. Nature 353, 225-229. 
Kennett, J. P., Hendy, I. L., Behl, R. J., 1996. Late Quaternary foraminiferal carbon isotopic record in Santa Barbara Basin: Implications for rapid climate change, EOS Trans., AGU 77 (46), 294.

Knab, N.J., Cragg, B.A., Borowski, C., Parkes, R.J., Pancost, R., Jørgensen, B.B., 2008. Anaerobic oxidation of methane (AOM) in marine sediments from the Skagerrak (Denmark): I. Geochemical and microbiological analyses. Geochim. Cosmochim. Acta 72, 2868-2879.

Knittel, K., Boetius, A., 2009. Anaerobic oxidation of methane: progress with an unknown process. Annual review of microbiology 63, 311-334.

Kudrass, H., Hofmann, A., Doose, H., Emeis, K., Erlenkeuser, H., 2001. Modulation and amplification of climatic changes in the Northern Hemisphere by the Indian summer monsoon during the past $80 \mathrm{ky}$. Geology 29, 63-66.

Kvenvolden, K.A., Lorenson, T.D., 2001. The global occurrence of natural gas hydrate. in Natural Gas Hydrate: Occurrence, Distribution and Detection, Geophys. Monogr. Ser., vol. 124, edited by C.K Paul and W.P Dillon, pp. 3-18. AGU, Washinton, D.C.

Kvenvolden, K., 1993. Gas hydrates - geological perspective and global change. Rev. Geophys 31, 173-187.

Lashof, D.A., Ahuja, D.R., 1990. Relative contributions of greenhouse gas emissions to global warming. Nature 344, 529-531.

Lee, D. H., Kim, J. H., Bahk, J. J., Cho, H. Y., Hyun, J. H., Shin, K. H., 2013. Geochemical signature related to lipid biomarkers of ANMEs in gas hydrate-bearing sediments in the Ulleung Basin, East Sea (Korea). Marine and Petroleum Geology 47, 125-135.

Leifer, I., Luyendyk, B.P., Boles, J., Clark, J.F., 2006. Natural marine seepage blowout: Contribution to atmospheric methane. Global biogeochemical cycles 20, GB3008.

Levin, L.A., Michener, R.H., 2002. Isotopic evidence for chemosynthesis-based nutrition of macrobenthos: the lightness of being at Pacific methane seeps. Limnol. Oceanogr. 47, 1336-1345.

Martin, P.A., Lea, D.W., Rosenthal, Y., Shackleton, N.J., Sarnthein, M., Papenfuss, T., 2002. Quaternary deep sea temperature histories derived from benthic foraminiferal $\mathrm{Mg} / \mathrm{Ca}$. Earth Planet. Sci. Lett. 198, 193-209.

Martin, J.B., Day, S.A., Rathburn, A.E., Perez, M.E., Mahn, C., Gieskes, J., 2004. Relationships between the stable isotopic signatures of living and fossil foraminifera in Monterey Bay, California. Geochem. Geophys. Geosyst. 5, Q04004.

Matsumoto, R., Borowski, W. S., 2000. Gas hydrate estimates from newly determined oxygen isotopic fractionation (alpha GH-IW) and $\delta^{18} \mathrm{O}$ anomalies of the interstitial waters: Leg 164, Blake Ridge, Proc. Ocean Drill. Program Sci. Results 164, 59-66.

Max, M.D., Johnson, A.H., Dillon, W.P., 2006. Economic geology of natural gas hydrate. Dordrecht, Netherlands, 341pp. Springer publishers. 
Mazumdar, A., Peketi, A., Dewangan, P., Badesab, F., Ramprasad, T., Ramana, M.V., Patil, D., J., Dayal, A., 2009a. Shallow gas charged sediments off the Indian west coast: Genesis and distribution. Mar. Geol. 267, 71-85.

Mazumdar, A., Dewangan, P., Joäo, H.M., Peketi, A., Khosla, V., Kocherla, M., Badesab, F.K., Joshi, R.K., Roxanne, P., Ramamurty, P.B., Karisiddaiah, S. M., Patil, D. J., Dayal, A. M., Ramprasad, T., Hawkesworth, C. J., Avanzenelli, R., 2009b. Evidence of paleo-cold seep activity from the Bay of Bengal, offshore India. Geochem. Geophys. Geosys. 10, Q06005.

Mazumdar, A., Joshi, R.K., Peketi, A., Kocherla, M., 2011. Occurrence of faecal pellet-filled simple and composite burrows in cold seep carbonates: A glimpse of a complex benthic ecosystem. Mar. Geol. 289, 117-121.

Mazumdar, A., H.M. Joao, A. Peketi, P. Dewangan, M. Kocherla, R.K. Joshi, Rarnprasad, T., 2012. Geochemical and geological constraints on the composition of marine sediment pore fluid: Possible link to gas hydrate deposits. Mar. Pet. Geol. 38, 35-52.

Niemann, H., Duarte, J., Hensen, C., Omoregie, E., Magalhaes, V. H., Elvert, M., Pinheiro, L. M. Kopf, A. Boetius, A. ,2006. Microbial methane turnover at mud volcanoes of the Gulf of Cadiz. Geochim. Cosmochim. Acta 70, 5336-5355.

Ohkushi, K.i., Ahagon, N., Uchida, M., Shibata, Y., 2005. Foraminiferal isotope anomalies from northwestern Pacific marginal sediments. Geochem. Geophys. Geosyst. 6, Q04005.

Orphan, V.J., House, C.H., Hinrichs, K.U., McKeegan, K.D., DeLong, E.F., 2001. Methaneconsuming archaea revealed by directly coupled isotopic and phylogenetic analysis. Science 293, 484487.

Panieri, G., Camerlenghi, A., Conti, S., Pini, G.A., Cacho, I., 2009. Methane seepages recorded in benthic foraminifera from Miocene seep carbonates, Northern Apennines (Italy). Palaeo. Palaeo. Palaeo. 284, 271-282.

Panieri, G., Camerlenghi, A., Cacho, I., Cervera, C.S., Canals, M., Lafuerza, S., Herrera, G., 2012. Tracing seafloor methane emissions with benthic foraminifera: Results from the Ana submarine landslide (Eivissa Channel, Western Mediterranean Sea). Mar. geol. 291, 97-112.

Peckmann, J., Thiel, V., 2004. Carbon cycling at ancient methane-seeps. Chem. Geol. 205, 443467.

Peketi, A., Mazumdar, A., Joshi, R.K, Patil, D., Srinivas, P., Dayal, A., 2012. Tracing the Paleo sulfate-methane transition zones and H2S seepage events in marine sediments: An application of C-SMo systematics. Geochem. Geophys. Geosyst. 13, Q10007.

Petrenko, V. V., Smith, A. M., Brook, E. J., Lowe, D., Riedel, K., Brailsford, G., \& Severinghaus, J. P.,2009. ${ }^{14} \mathrm{CH}_{4}$ measurements in Greenland ice: investigating last glacial termination $\mathrm{CH}_{4}$ sources. Science 324, 506-508. 
Pitrowski, A.M., Banakar, V.K., Scrivner, A.E., Elderfield, H., Galy, A., Dennis, A., 2009. Indian Ocean circulation and productivity during the last glacial cycle. Earth Planet. Sci. Lett. 285, 179189.

Ramana, M., Ramprasad, T., Raju, K., Desa, M., 2007. Occurrence of gas hydrates along the continental margins of India, particularly the Krishna-Godavari offshore basin. Intern. J. Envior. Studies. 64, 675-693.

Rao, G., 2001. Sedimentation, stratigraphy, and petroleum potential of Krishna-Godavari basin, East Coast of India. Amer. Assoc. Petrol. Geol. 85, 1623-1643.

Rao, G., Mani, K., 1993. A study on generation of abnormal pressures in Krishna Godavari basin. Indian J. Petrol. Geol. 2, 20-30.

Rathburn, A.E., Levin, L.A., Held, Z., Lohmann, K.C., 2000. Benthic foraminifera associated with cold methane seeps on the northern California margin: ecology and stable isotopic composition. Marine Micropal. 38, 247-266.

Reeburgh, W.S., 2007. Oceanic methane biogeochemistry. Chem. Rev. 107, 486-513.

Riedel, M., Collett, T., Kumar, P., Sathe, A., Cook, A., 2010. Seismic imaging of a fractured gas hydrate system in the Krishna-Godavari Basin offshore India. Mar. Pet. Geol. 27, 1476-1493.

Sanchez Goni, M.F., Landais, A., Fletcher, W.J., Naughton, F., Desprat, S., Duprat, J., 2008. Contrasting impacts of Dansgaard-Oeschger events over a western European latitudinal transect modulated by orbital parameters. Quat. Sc. Rev. 27, 1136-1151.

Sauter, E.J., Muyakshin, S.I., Charlou, J.L., Schluter, M., Boetius, A., Jerosch, K., Damm, E., Foucher, J.-P., Klages, M., 2006. Methane discharge from a deep-sea submarine mud volcano into the upper water column by gas hydrate-coated methane bubbles. Earth Planet. Sci. Lett. 243, 354-365.

Sen Gupta, B.K, Platon, E., Bernhard, J.M., Aharon, P., 1997. Foraminiferal colonization of hydrocarbon-seep bacterial mats and underlying sediment, Gulf of Mexico slope. J. Foraminiferal Res. 27, 292-300.

Shankar, U., Riedel, M., 2010. Seismic and heat flow constraints from the gas hydrate system in the Krishna-Godavari Basin, India. Mar. Geol. 276, 1-13.

Singh, S.C., Minshull, T.A., Spence, G.D., 1993. Velocity structure of a gas hydrate reflector. Science 260, 204-207.

Sloan, E. D., 1998. Clathrate hydrates of natural gases. (2nd edition), 730 pp., New York, Marcel Dekker Inc.

Smith, L. M., Sachs, J. P., Jennings, A. E., Anderson, D. M., deVernal, A., 2001. Light $\delta^{13}$ C events during deglaciation of the East Greenland continental shelf attributed to methane release from gas hydrates. Geophys. Res. Lett. 28, 2217-2220. 
Spero, H.J., Lea, D.W., 2002. The cause of carbon isotope minimum events on glacial terminations. Science 296, 522-525.

Sowers, T., 2006. Late quaternary atmospheric $\mathrm{CH}_{4}$ isotope record suggests marine clathrates are stable. Science 311, 838-840.

Stott, L.D., Bunn, T., Prokopenko, M., Mahn, C., Gieskes, J., Bernhard, J.M., 2002. Does the oxidation of methane leave an isotopic fingerprint in the geologic record? Geochem. Geophys. Geosyst. 3.

Thiel, V., Peckmann, J.. Richnow, H. H., Luth, U., Reitner, J., Michaelis W.,2001. Molecular signals for anaerobic methane oxidation in Black Sea seep carbonates and a microbial mat, Mar. Chem. $73,97-112$.

Torres, M.E., Martin, R.A., Klinkhammer, G.P., Nesbitt, E.A., 2010. Post depositional alteration of foraminiferal shells in cold seep settings: new insights from flow-through time-resolved analyses of biogenic and inorganic seep carbonates. Earth Planet. Sci. Lett. 299, 10-22.

Uchida, M., Shibata, Y., Ohkushi, K.i., Ahagon, N., Hoshiba, M., 2004. Episodic methane release events from Last Glacial marginal sediments in the western North Pacific. Geochem. Geophys. Geosyst. 5, Q08005.

Uchida, M., Ohkushi, K.i., Kimoto, K., Inagaki, F., Ishimura, T., Tsunogai, U., TuZino, T., Shibata, Y., 2008. Radiocarbon-based carbon source quantification of anomalous isotopic foraminifera in last glacial sediments in the western North Pacific. Geochem. Geophys. Geosyst. 9.

Valentine, D.L., 2002. Biogeochemistry and microbial ecology of methane oxidation in anoxic environments: a review. Antonie Van Leeuwenhoek 81, 271-282.

Valentine, D., Reeburgh, W., 2000. New perspectives on anaerobic methane oxidation. Environ. Microbiol. 2, 477-484.

Waelbroeck, C., Labeyrie, L., Michel, E., Duplessy, J.C., McManus, J.F., Lambeck, K., Balbon, E., Labracherie, M., 2002. Sea-level and deep water temperature changes derived from benthic foraminifera isotopic records. Quat. Sci. Rev. 21, 295-305.

Walter, K.M., Zimov, S.A., Chanton, J.P., Verbyla, D., Chapin, F.S., 2006. Methane bubbling from Siberian thaw lakes as a positive feedback to climate warming. Nature 443, 71-75.

Wang, S., Yan, B., Yan, W., 2013. Tracing seafloor methane emissions with benthic foraminifera in the Baiyun Sag of the northern South China Sea. Environ. Earth Sci. 70, 1143-1150.

Wefer, G., Heinze, P.M., Berger, W.H., 1994. Clues to ancient methane release. Nature 369, 282.

Weijers, J. W., Lim, K. L., Aquilina, A., Sinninghe Damsté, J. S., \& Pancost, R. D., 2011. Biogeochemical controls on glycerol dialkyl glycerol tetraether lipid distributions in sediments characterized by diffusive methane flux. Geochemistry, Geophysics, Geosystems, 12, 1-15 
Wiedicke, M., Weiss, W., 2006. Stable carbon isotope records of carbonates tracing fossil seep activity off Indonesia. Geochem. Geophys. Geosyst. 7.

Wolff, E., Spahni, R., 2007. Methane and nitrous oxide in the ice core record. Philosophical Transactions of the Royal Society A: Mathematical, Physical and Engineering Sciences 365, 1775-1792.

Wu, S., Bally, A.W., 2000. Slope Tectonics-comparisons and Contrasts of Structural Styles of Salt and Shale Tectonics of the Northern Gulf of Mexico with Shale Tectonics of Offshore Nigeria in Gulf of Guinea. Atlantic rifts and continental margins 115, 151-172.

Zhang, Y.,2003. Methane escape from gas hydrate systems in marine environment, and methanedriven oceanic eruptions, Geophys. Res. Lett. 30, 51-1 to 51-4, doi:10.1029/2002GL016658.

Zhiguang, S., Wang, C., 2006. The biomarkers of 2,6,10,15, 19-pentamethylicosenes and their carbon isotopic composition in the sediments from the Gulf of Mexico. Chinese Sci.Bull. 51, 17361740. 


\section{Figure and Table Captions}

Figure-1. Contour map of K-G Basin showing core locations of MD161-8 and 15 and NGHP10-D, 5D and $6 \mathrm{C}$.

Figure 2. Grain size and wet bulk density data of MD161-8 and MD161-15. The rectangular box in B and D represents zone of authigenic carbonate enrichment. Chemosynthetic clam shell occurrences and Mo concentration anomaly are reported with the depth zone of 16-18 mbsf (box in B)

Figure-3 Scanning electron micrographs of representative samples of G. ruber and Uvigerina sp. analysed for carbon and oxygen stable isotope ratio in core MD161-8. (A, C) G. ruber with clean outer shell surface and open pores. (B, D). Arrow in $\mathrm{C}$ shows well preserved spines. (E, F) Uvigerina sp. showing smooth outer shell surface and well preserved ornamentations.

Figure-4. An age model for the core MD161-8. A. $\delta^{18} \mathrm{O}_{\text {G.ruber }}$ profile from Bay of Bengal (modified after Kudrass et al. 2001), B. $\delta^{18} \mathrm{O}_{G \text {.ruber }}$ profile of MD161-8 from K-G basin, Bay of Bengal. YD= younger Dryas, $\mathrm{B} / \AA$ = Bølling-Allerød interstadial, LGM = last glacial maxima. $\mathrm{D}-\mathrm{O}=$ Daansgaard-Oeschger events.

Figure-5. An age model for the core MD161-15.

Figure 6. (A-D) $\delta^{18} \mathrm{O}$ and $\delta^{13} \mathrm{C}$ profiles for G.ruber and Uvigerina sp in core MD161-8. $\mathrm{P}_{1}$ to $\mathrm{P}_{6}$ and $\mathrm{B}_{1}$ to $\mathrm{B}_{3}$ represent $\delta^{13} \mathrm{C}$ peaks of planktic and benthic foraminifera respectively. $\mathrm{YD}, \mathrm{B} / \AA$, D-O, MIS and LGM represent the Younger Dryas, Bølling/Ållerød, Dansgaard-Oeschger, marine isotope stages and last glacial maxima respectively. The colored zone represents different marine isotope stages. (E) Bulk organic matter carbon stable isotope ratios and TOC/TN ratios of MD161-8. Samples enriched in PMI are marked by arrows. The carbon isotope ratios are given in bracket as permil VPDB.

Figure 7. Cross plot of $\delta^{13} \mathrm{C}$ and $\delta^{18} \mathrm{O}$ of benthic (A and $\mathbf{B}$ ) and planktic (C and D) foraminifera in MD161-8, along with authigenic carbonate data from MD161-8 from Mazumdar et al.,2009.

Figure 8. A. Morphology of authigenic carbonates and shells in the carbonate riched zone of MD16115. (i-iv) Mudstone concretion with gas flow conduit (chimney). (v-vi) Scaphopoda shell penetrating into the carbonate sediment.

Figure 9. A and B. Fragment of Calyptogena sp. shell external and internal surfaces, C. external surface of Lucinoma sp. The shell fragments are recovered from MD161-15. The gray colored sediment adhered to the shell surfaces are the authigenic carbonates.

Figure 10A. Total inorganic carbon content (TIC wt $\%$ ) and $\delta^{13} \mathrm{C}_{\mathrm{TIC}}$ profile of MD161-8. $\delta^{13} \mathrm{C}_{\mathrm{TIC}}$ values are from Peketi et al. (2012); 10B. TOC content ( TOC wt\%) of MD161-8.

Figure 11. GC-MS spectra showing PMI peak (short arrow) and structure of 2,6,10,15,19pentamethylicosane. PMI data is from MD161-8. 


\section{Supplementary Table and Figure captions}

Suppl. Table 1. Carbon and oxygen stable isotope ratios of planktic foraminifera (G. ruber) of MD161-8.

Suppl. Table- 2. Carbon and oxygen stable isotope ratios of benthic foraminifera (Uvigerina $s p$ ) of MD161-8.

Suppl. Table-3. Mineralogy and $\delta^{13} \mathrm{C}-\delta^{18} \mathrm{O}$ values of authigenic carbonate samples from MD161-15.

Suppl. Table-4. Total organic carbon content (TOC wt \%), $\delta^{13} \mathrm{C}_{\mathrm{TOC}}(\%$ VPDB) and Total inorganic carbon content (TIC wt\%) in MD161-8.

\section{Supplementary Figure}

Suppl. Figure-1. Temperature, salinity and dissolved oxygen profiles of sea water column near site MD161-8.

Suppl. Figure-2. Blowup of the benthic and planktic foraminifera carbon and oxygen isotope profiles within the age bracket (59000-79000 y BP). 


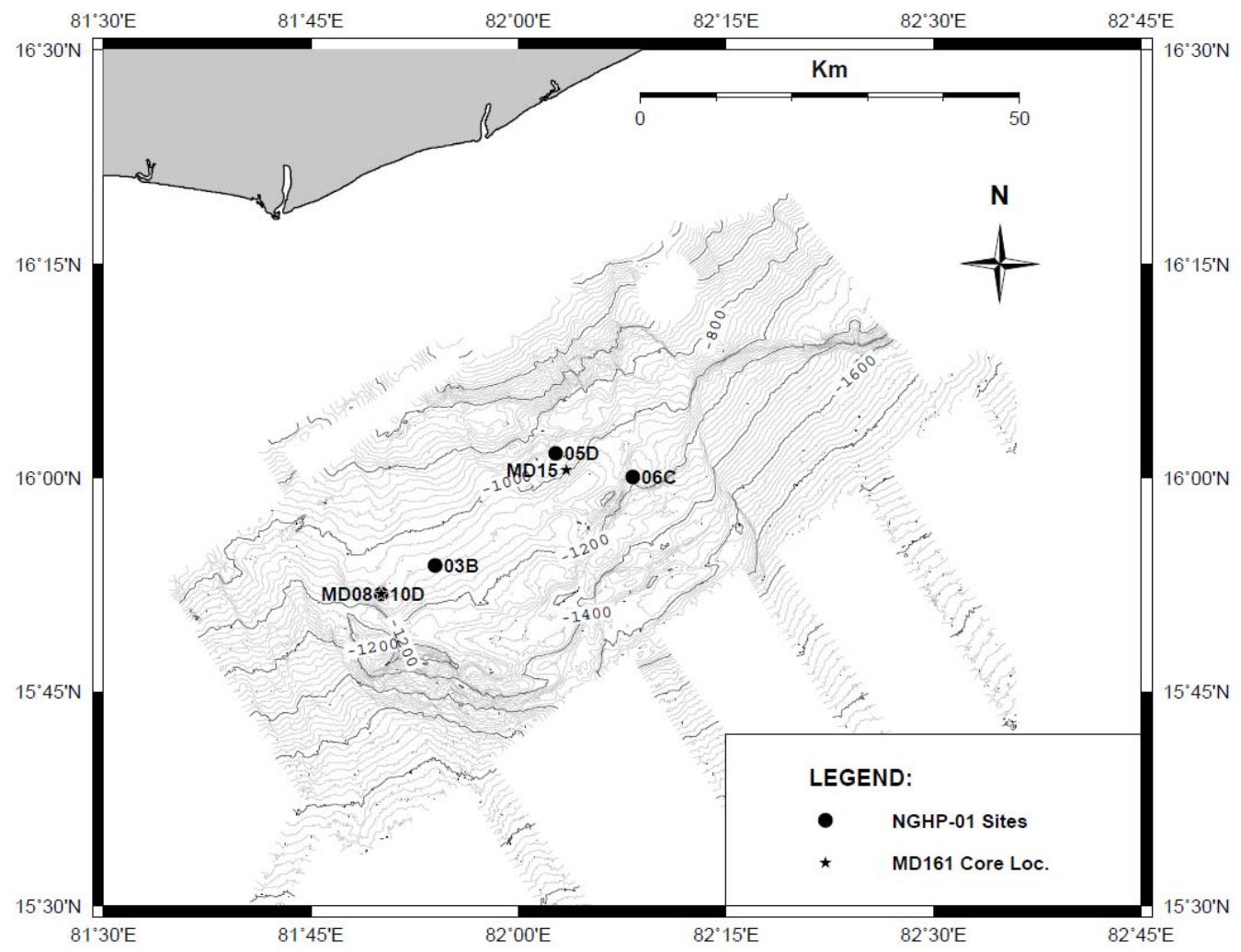

Fig.1
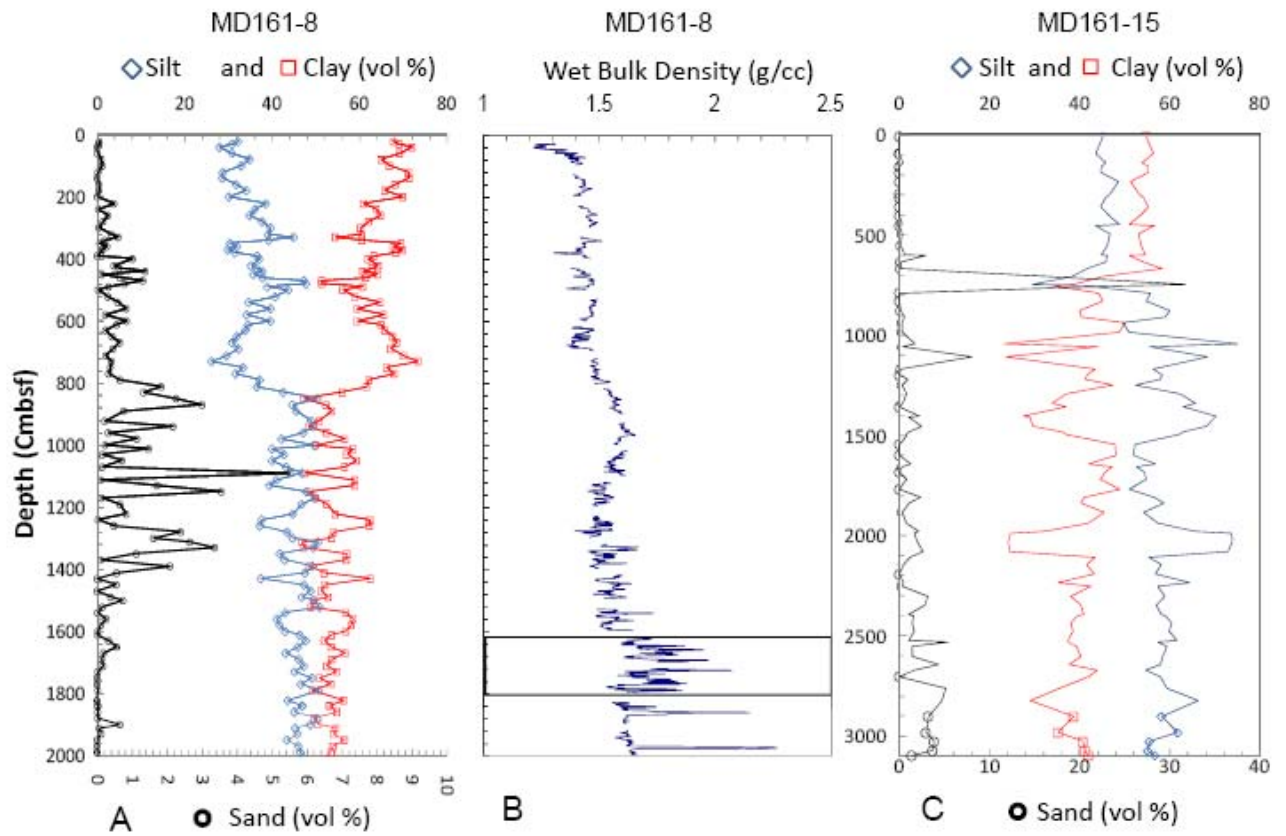

MD161-15

Wet Bulk Density (g/cc)

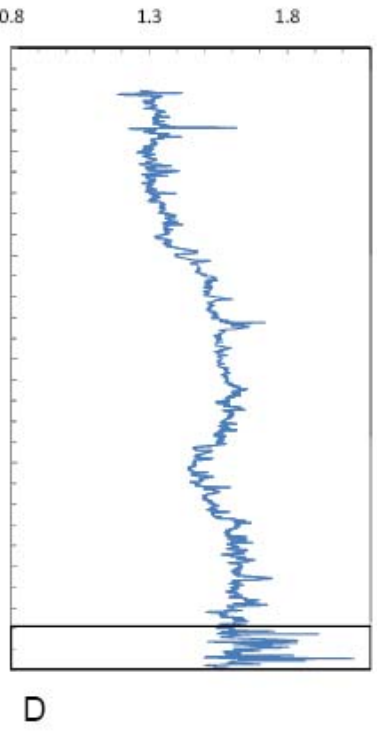

Fig. 2 

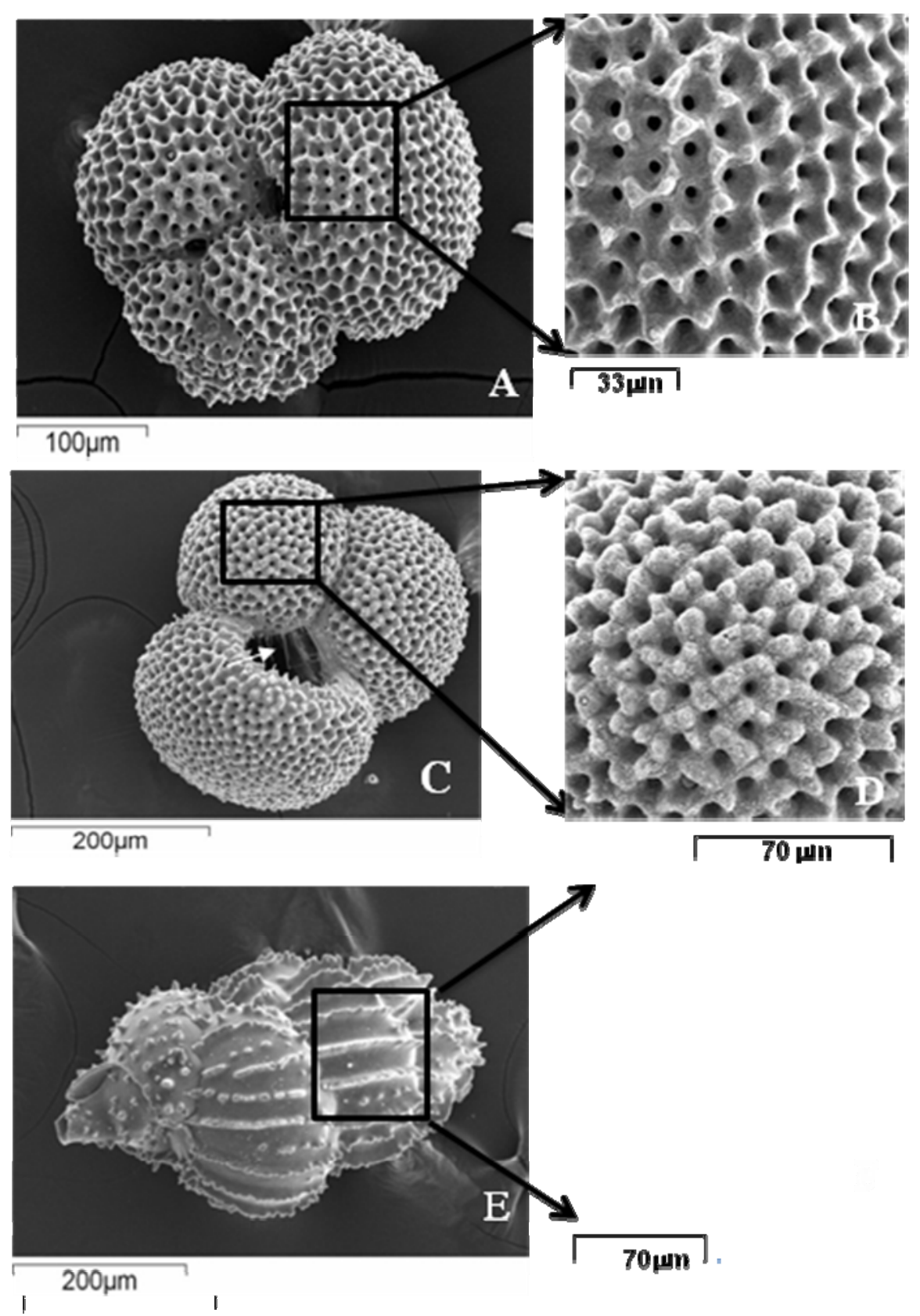

Fig.3 


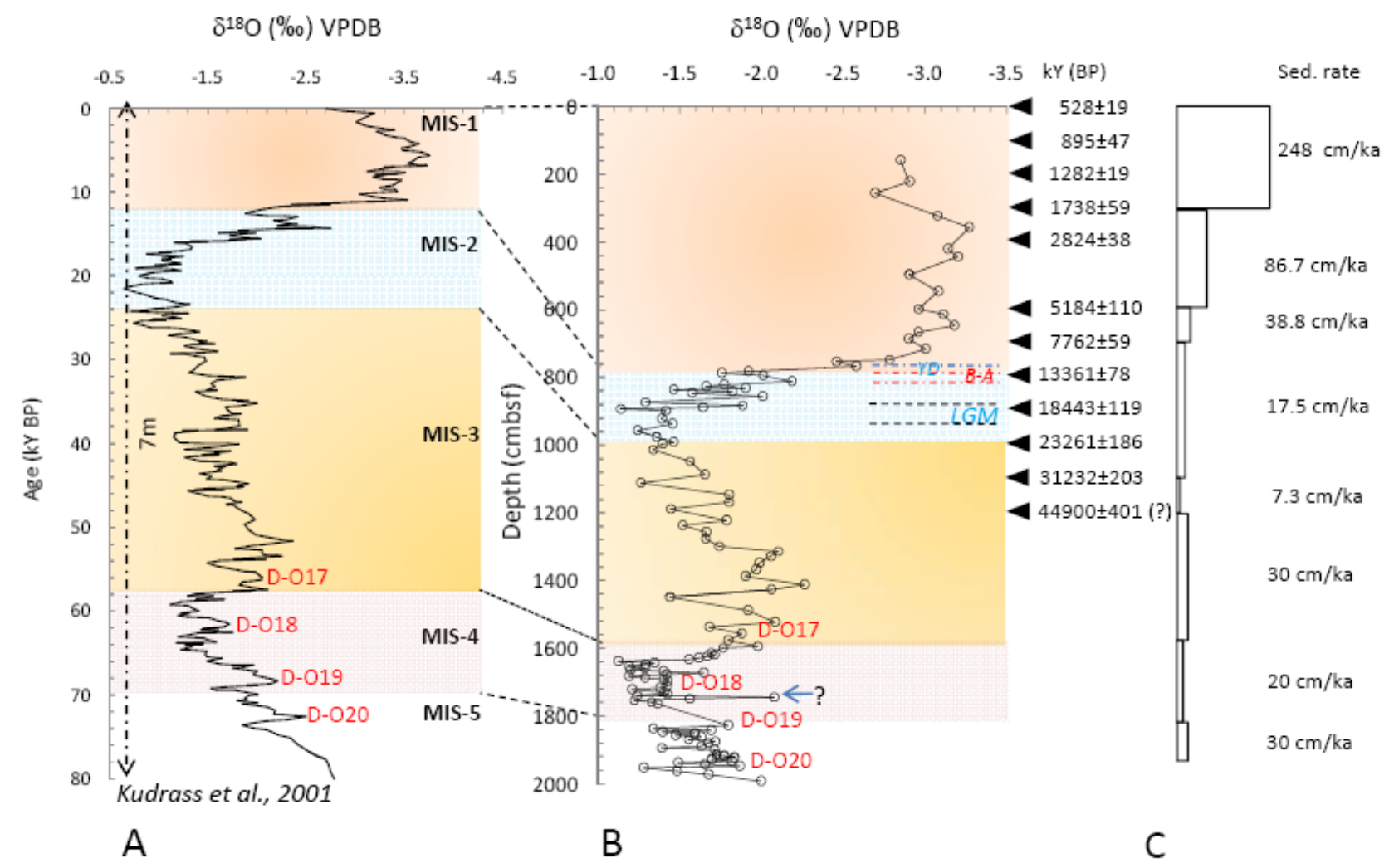

Fig.4 


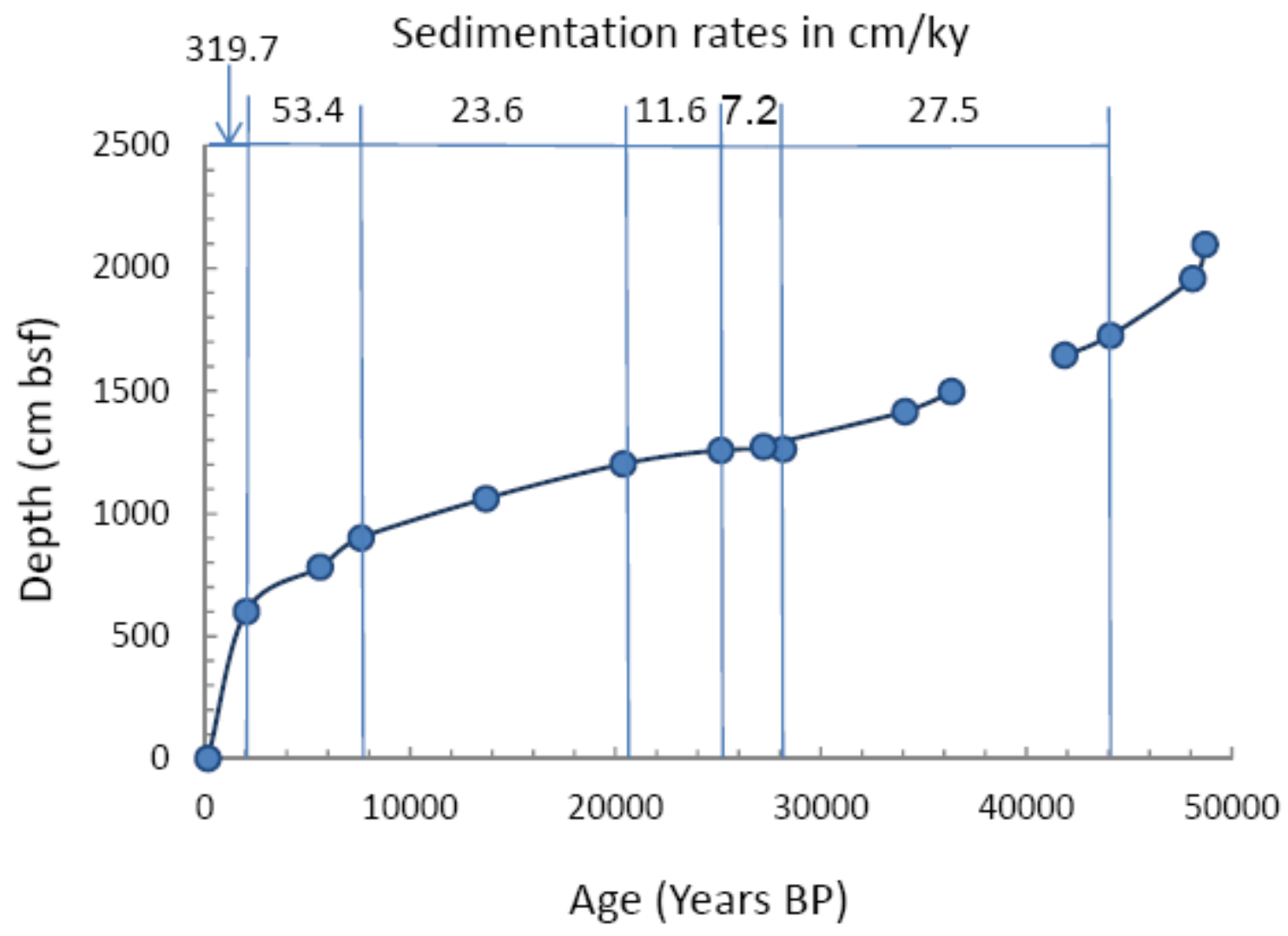

Fig.5 


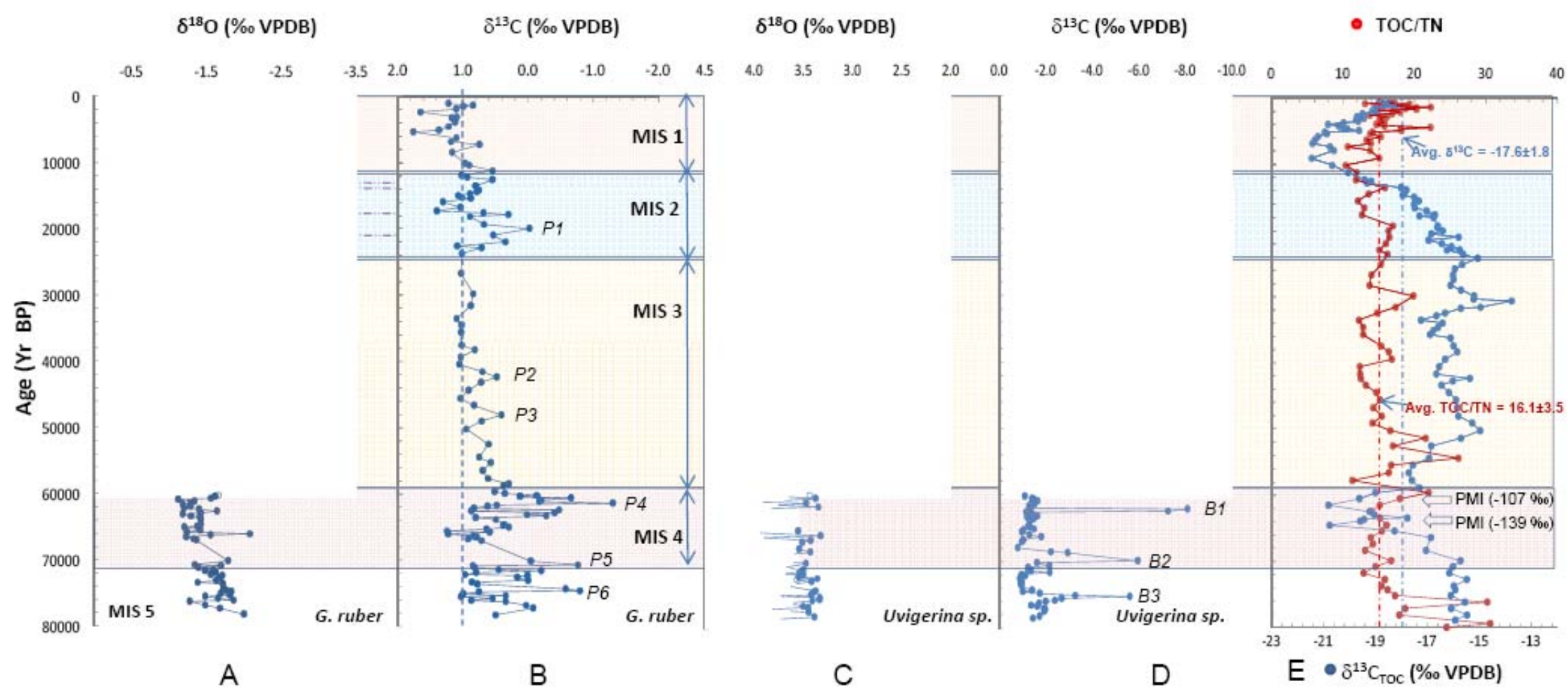

Fig.6 

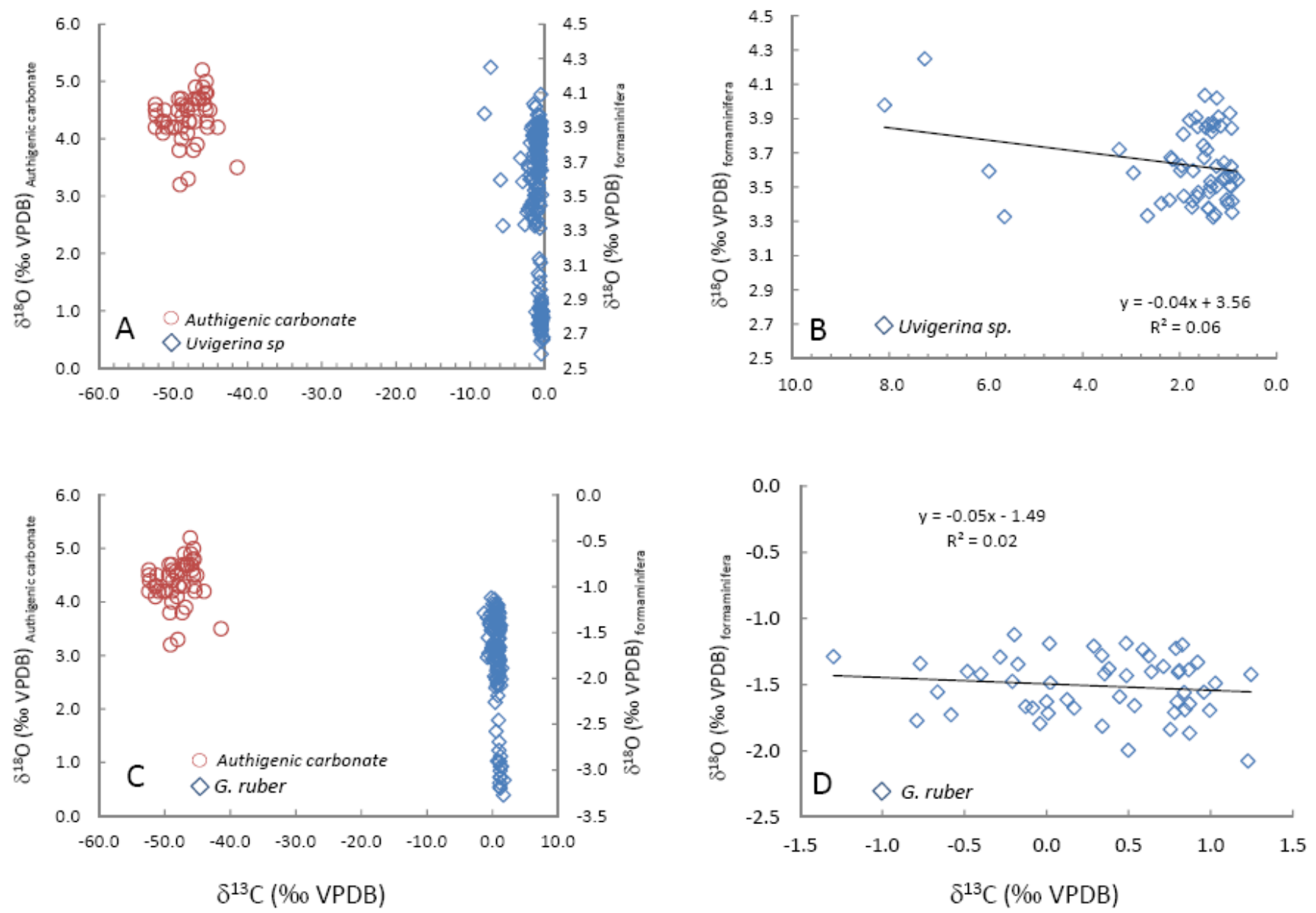

Fig.7 


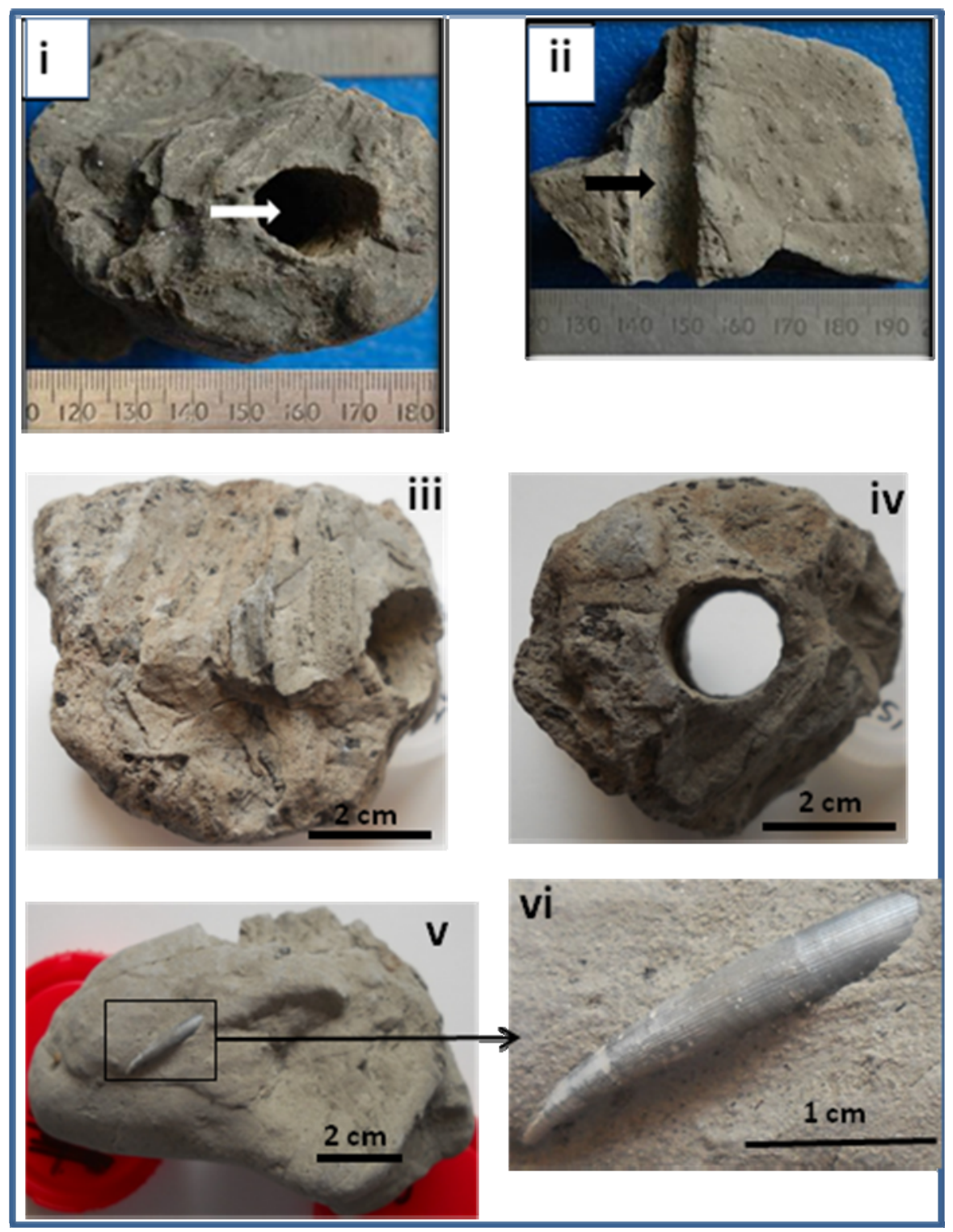

Fig. 8 

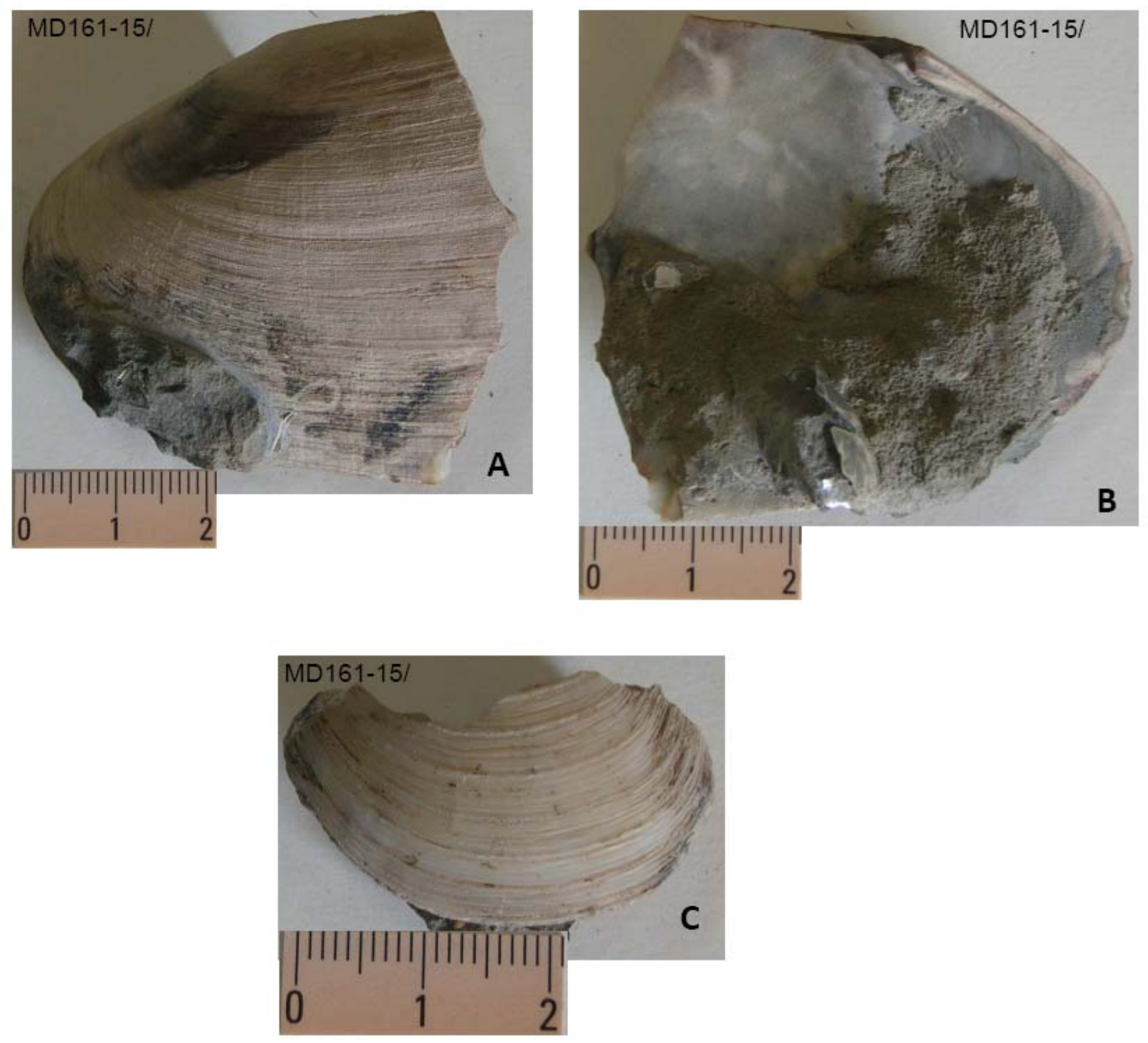

Fig.9 

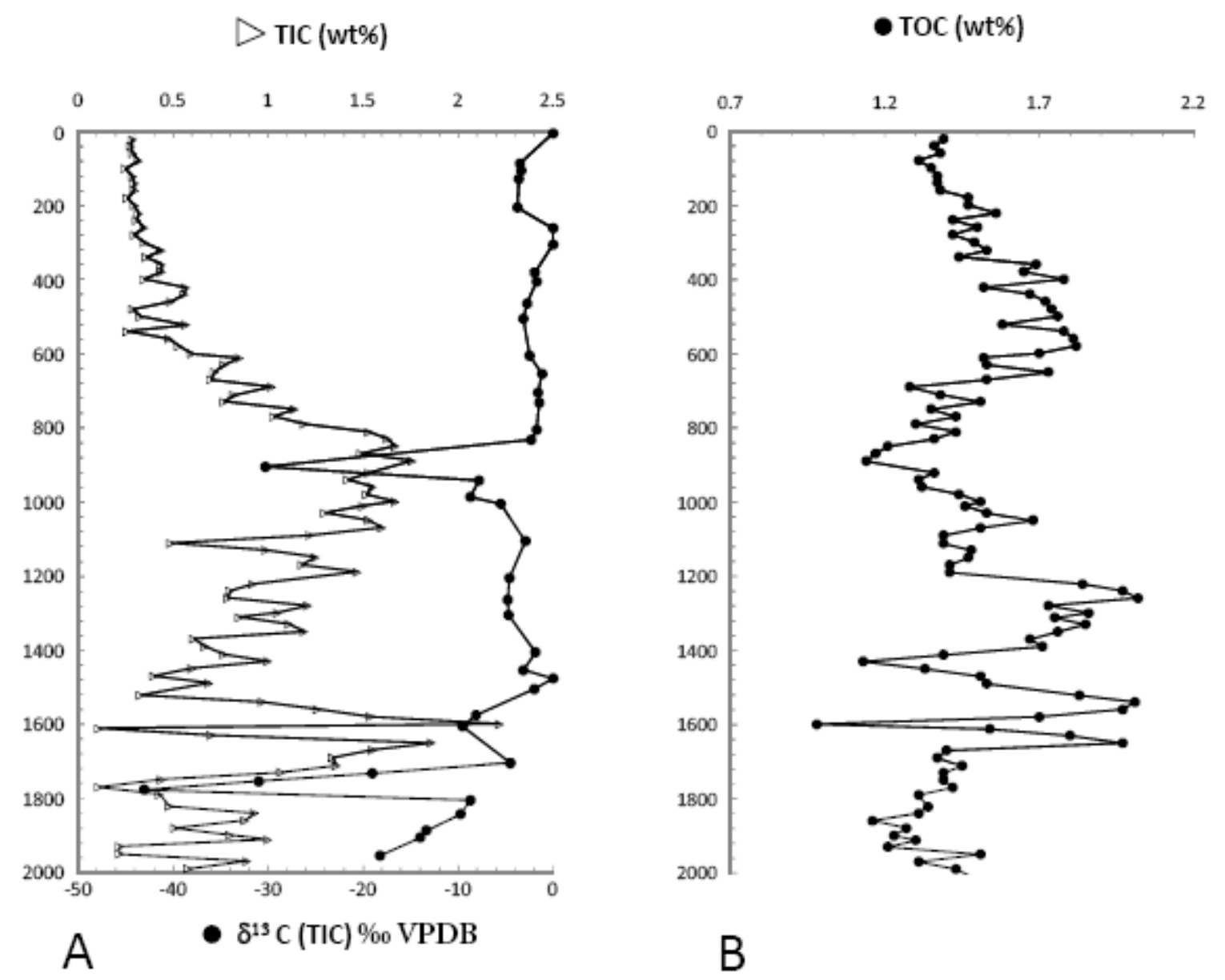

Fig.10 
Structure of PMI

Molecular formula: $\mathrm{C}_{25} \mathrm{H}_{52}$

Molecular weight: 352

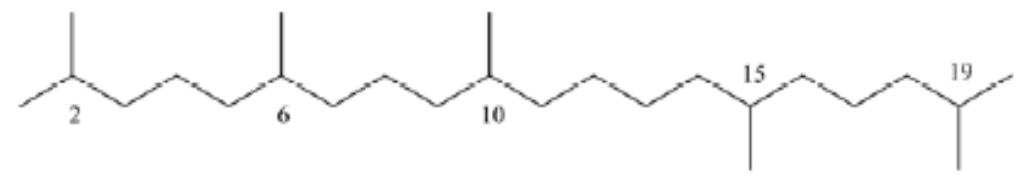

2,6,10,15,19-pentamethylicosane

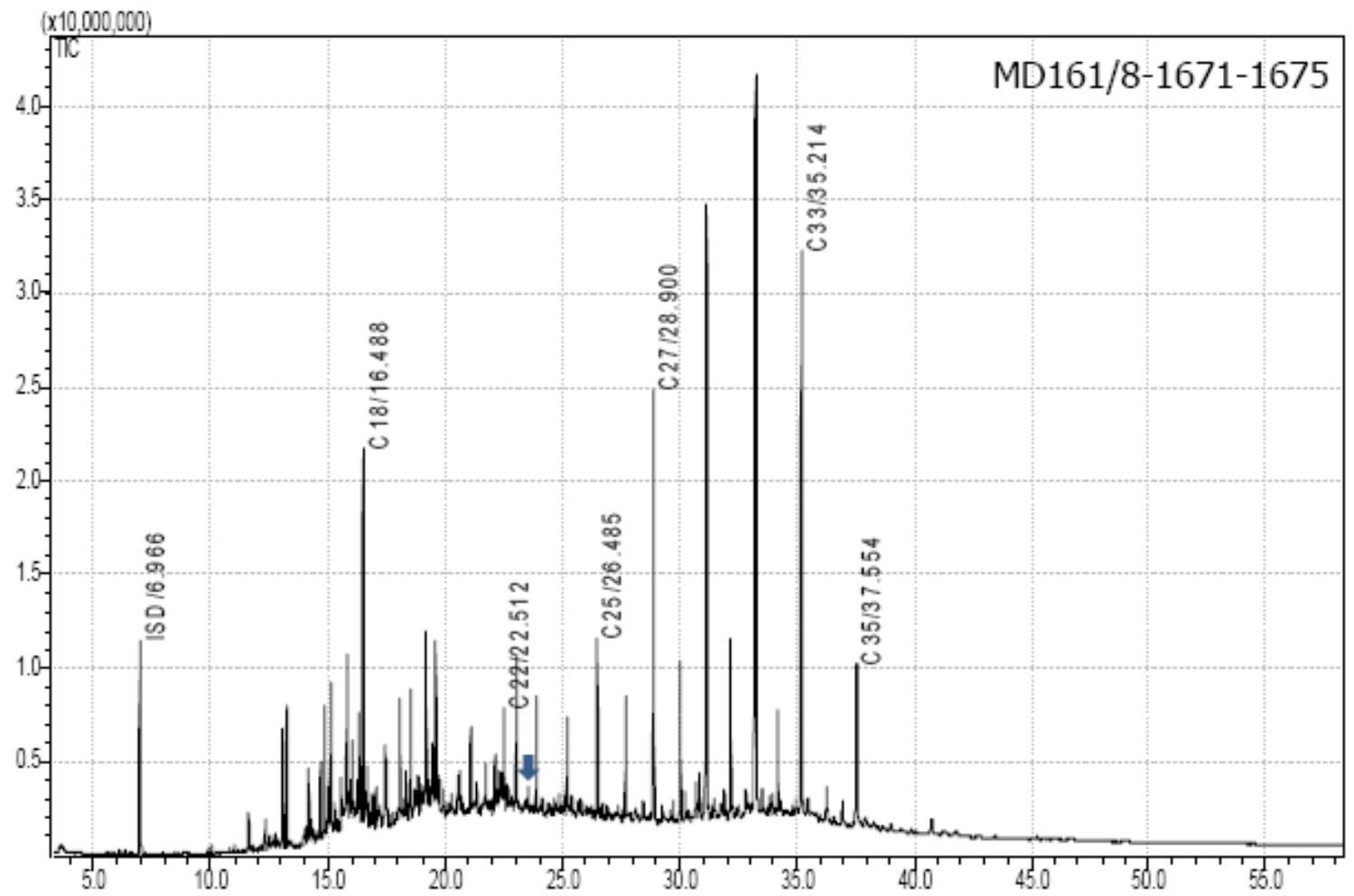

Fig.11 


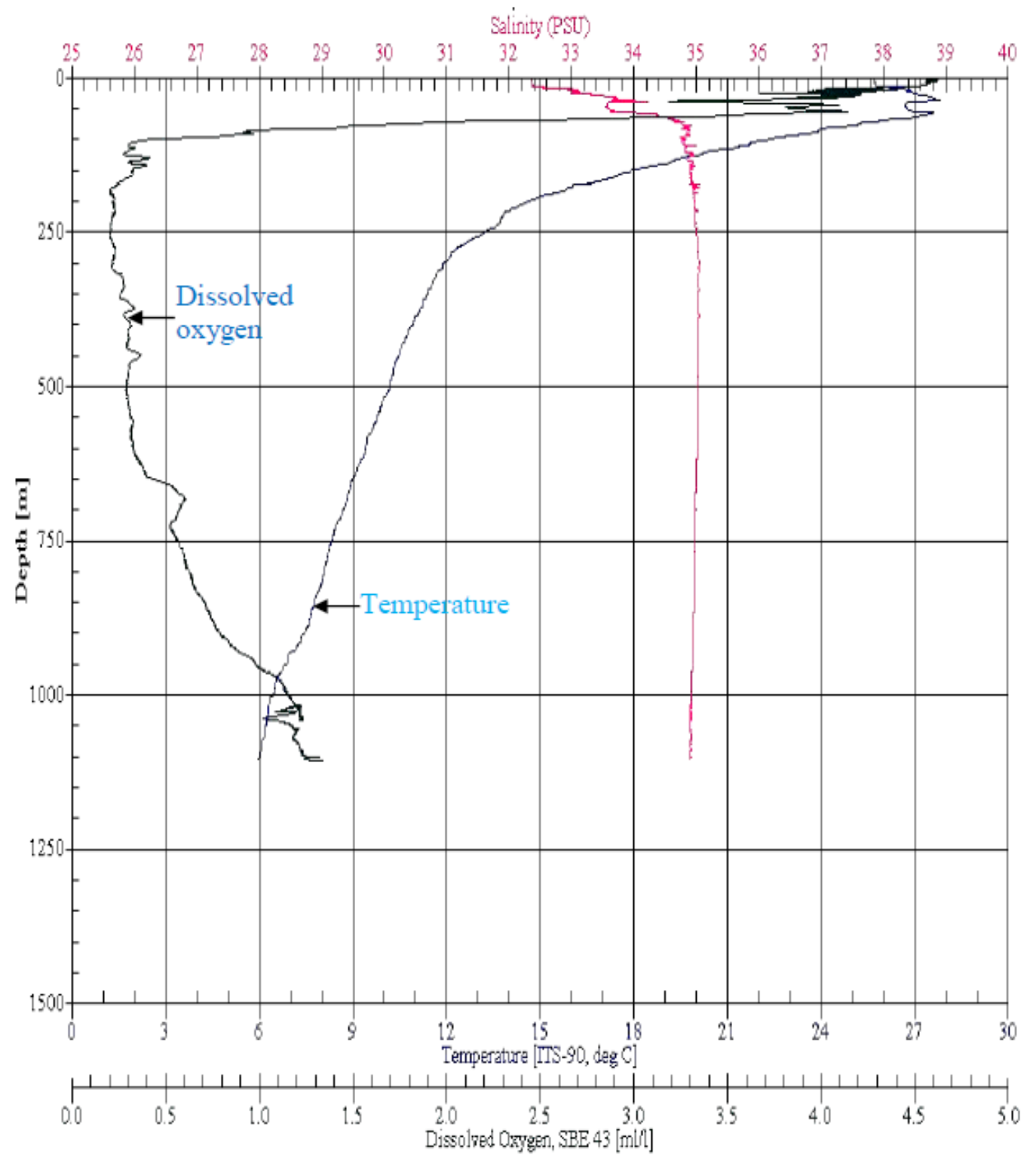

Supplimentary Fig-1. Temperature, salinity and dissolved oxygen profiles of sea water column near site MD161-8. 


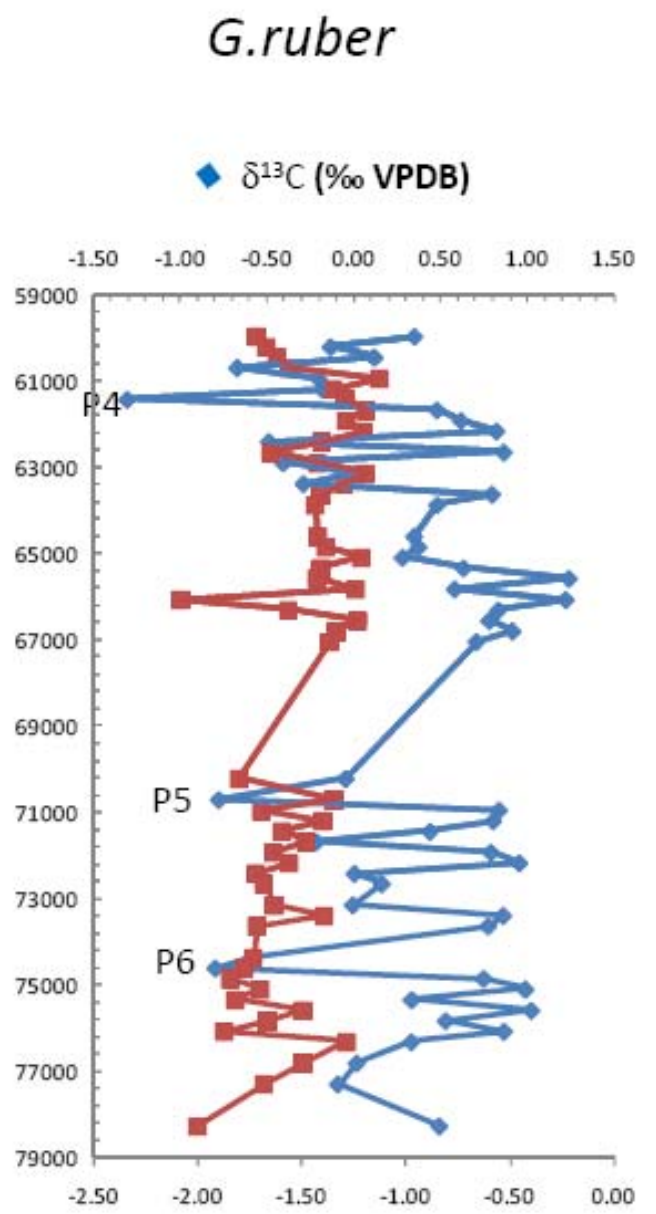

$A \quad \delta^{18} \mathrm{O}(\%$ VPDB $)$
Uvigerina sp.

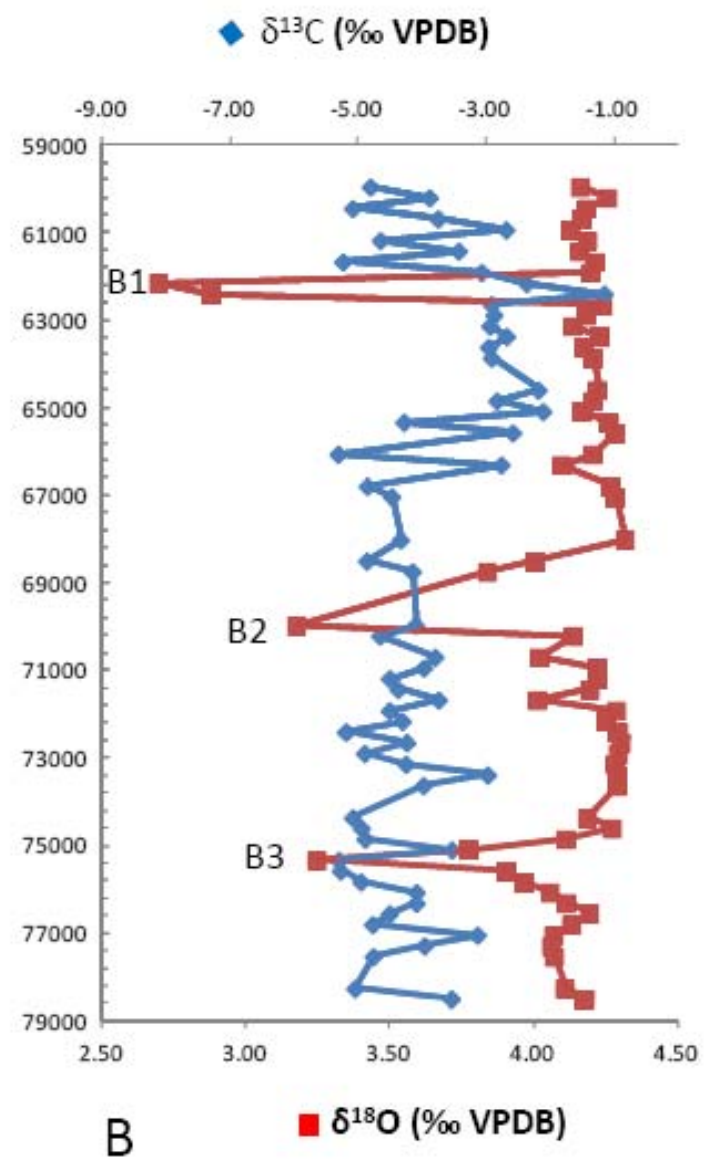

B

Suppl. Figure-2. Blowup of the benthic and planktic foraminifera carbon and oxygen isotope profiles within the age bracket (59000-79000 y BP). 
Table TS 1. Carbon and oxygen stable isotope ratios of planktic foraminifera (G. ruber) of MD161-8.

\begin{tabular}{|c|c|c|c|}
\hline $\begin{array}{c}\text { Mean Depth } \\
\text { (Cmbsf) }\end{array}$ & Age (y) & $\delta^{18} \mathrm{C}\left(\%{ }^{2} \mathrm{VPDB}\right)$ & $\delta^{13} \mathrm{O}(\% 0 \mathrm{VPDB})$ \\
\hline 157.5 & 1097.7 & 1.22 & -2.85 \\
\hline 222.5 & 1375.5 & 0.85 & -2.90 \\
\hline 257.5 & 1523.3 & 0.99 & -2.69 \\
\hline 322.5 & 1907.4 & 1.10 & -3.08 \\
\hline 357.5 & 2311.0 & 1.65 & -3.27 \\
\hline 422.5 & 3060.4 & 1.09 & -3.14 \\
\hline 442.5 & 3291.0 & 1.17 & -3.20 \\
\hline 497.5 & 3925.2 & 1.12 & -2.91 \\
\hline 547.5 & 4501.7 & 1.22 & -3.08 \\
\hline 597.5 & 5078.2 & 1.37 & -2.96 \\
\hline 612.5 & 5364.3 & 1.75 & -3.11 \\
\hline 647.5 & 6266.6 & 1.09 & -3.18 \\
\hline 667.5 & 6782.2 & 1.17 & -2.96 \\
\hline 687.5 & 7297.8 & 0.75 & -2.90 \\
\hline 717.5 & 8485.5 & 1.16 & -3.01 \\
\hline 747.5 & 10087.0 & 0.97 & -2.79 \\
\hline 752.5 & 10351.0 & 0.91 & -2.46 \\
\hline 767.5 & 11155.9 & 0.54 & -2.58 \\
\hline 782.5 & 11957.2 & 1.02 & -1.92 \\
\hline 787.5 & 12224.3 & 0.92 & -1.76 \\
\hline 794.5 & 12598.2 & 0.55 & -2.01 \\
\hline 812.5 & 13559.8 & 0.81 & -2.19 \\
\hline 822.5 & 14095.0 & 0.76 & -1.77 \\
\hline 827.5 & 14361.1 & 0.79 & -1.66 \\
\hline 832.5 & 14629.2 & 0.88 & -1.90 \\
\hline 837.5 & 14895.3 & 1.07 & -1.47 \\
\hline 842.5 & 15163.4 & 1.01 & -1.82 \\
\hline 847.5 & 15429.5 & 0.88 & -1.57 \\
\hline 857.5 & 15964.7 & 1.30 & -2.01 \\
\hline 872.5 & 16765.0 & 1.04 & -1.29 \\
\hline 882.5 & 17300.2 & 1.40 & -1.89 \\
\hline 887.5 & 17566.3 & 0.68 & -1.64 \\
\hline 892.5 & 17834.4 & 0.30 & -1.14 \\
\hline 897.5 & 18100.5 & 0.88 & -1.41 \\
\hline 922.5 & 19267.1 & 0.67 & -1.39 \\
\hline 937.5 & 19985.9 & -0.03 & -1.45 \\
\hline 957.5 & 20949.9 & 0.53 & -1.25 \\
\hline 977.5 & 21910.4 & 0.35 & -1.36 \\
\hline 992.5 & 22624.7 & 1.09 & -1.47 \\
\hline
\end{tabular}




\begin{tabular}{|c|c|c|c|}
\hline 997.5 & 22869.0 & 0.72 & -1.39 \\
\hline 1012.5 & 23645.6 & 1.01 & -1.34 \\
\hline 1047.5 & 26650.9 & 1.03 & -1.57 \\
\hline 1087.5 & 29765.3 & 0.84 & -1.66 \\
\hline 1112.5 & 31607.6 & 0.88 & -1.26 \\
\hline 1147.5 & 33485.4 & 1.09 & -1.80 \\
\hline 1167.5 & 34558.4 & 1.02 & -1.80 \\
\hline 1187.5 & 35631.4 & 1.03 & -1.44 \\
\hline 1222.5 & 37509.1 & 1.02 & -1.78 \\
\hline 1237.5 & 38313.9 & 0.81 & -1.52 \\
\hline 1257.5 & 39386.9 & 1.02 & -1.66 \\
\hline 1277.5 & 40459.9 & 1.05 & -1.66 \\
\hline 1297.5 & 41532.9 & 0.69 & -1.74 \\
\hline 1312.5 & 42362.0 & 0.48 & -2.10 \\
\hline 1327.5 & 43229.9 & 0.73 & -2.05 \\
\hline 1347.5 & 44383.9 & 0.91 & -1.99 \\
\hline 1367.5 & 45536.9 & 1.03 & -1.97 \\
\hline 1387.5 & 46689.9 & 0.83 & -1.90 \\
\hline 1412.5 & 48137.1 & 0.40 & -2.26 \\
\hline 1427.5 & 49007.9 & 0.71 & -2.06 \\
\hline 1447.5 & 50167.9 & 0.94 & -1.44 \\
\hline 1487.5 & 52469.0 & 0.61 & -1.91 \\
\hline 1522.5 & 54506.6 & 0.74 & -2.08 \\
\hline 1537.5 & 55358.6 & 0.57 & -1.68 \\
\hline 1557.5 & 56519.7 & 0.70 & -1.88 \\
\hline 1577.5 & 57669.3 & 0.62 & -1.79 \\
\hline 1592.5 & 58535.5 & 0.30 & -1.98 \\
\hline 1597.5 & 58820.5 & 0.37 & -1.77 \\
\hline 1612.5 & 59720.0 & 0.51 & -1.69 \\
\hline 1617.5 & 59964.0 & 0.36 & -1.71 \\
\hline 1622.5 & 60208.0 & -0.13 & -1.66 \\
\hline 1627.5 & 60452.0 & 0.12 & -1.61 \\
\hline 1632.5 & 60696.0 & -0.66 & -1.55 \\
\hline 1637.5 & 60940.0 & -0.20 & -1.12 \\
\hline 1642.5 & 61184.0 & -0.17 & -1.34 \\
\hline 1647.5 & 61428.0 & -1.30 & -1.29 \\
\hline 1652.5 & 61672.0 & 0.48 & -1.19 \\
\hline 1657.5 & 61916.0 & 0.62 & -1.28 \\
\hline 1662.5 & 62160.0 & 0.83 & -1.20 \\
\hline 1667.5 & 62404.0 & -0.48 & -1.40 \\
\hline 1672.5 & 62648.0 & 0.87 & -1.64 \\
\hline 1677.5 & 62892.0 & -0.40 & -1.42 \\
\hline 1682.5 & 63136.0 & 0.02 & -1.19 \\
\hline
\end{tabular}




\begin{tabular}{|c|c|c|c|}
\hline 1687.5 & 63380.0 & -0.28 & -1.29 \\
\hline 1692.5 & 63624.0 & 0.80 & -1.41 \\
\hline 1697.5 & 63868.0 & 0.49 & -1.43 \\
\hline 1712.5 & 64600.0 & 0.35 & -1.42 \\
\hline 1717.5 & 64844.0 & 0.38 & -1.38 \\
\hline 1722.5 & 65088.0 & 0.29 & -1.21 \\
\hline 1727.5 & 65332.0 & 0.64 & -1.40 \\
\hline 1732.5 & 65576.0 & 1.25 & -1.42 \\
\hline 1737.5 & 65820.0 & 0.59 & -1.24 \\
\hline 1742.5 & 66064.0 & 1.23 & -2.08 \\
\hline 1747.5 & 66308.0 & 0.84 & -1.56 \\
\hline 1752.5 & 66552.0 & 0.79 & -1.23 \\
\hline 1757.5 & 66796.0 & 0.92 & -1.33 \\
\hline 1762.5 & 67040.0 & 0.71 & -1.36 \\
\hline 1827.5 & 70212.0 & -0.04 & -1.79 \\
\hline 1837.5 & 70700.0 & -0.77 & -1.34 \\
\hline 1842.5 & 70944.0 & 0.84 & -1.69 \\
\hline 1847.5 & 71188.0 & 0.81 & -1.39 \\
\hline 1852.5 & 71432.0 & 0.45 & -1.59 \\
\hline 1857.5 & 71676.0 & -0.21 & -1.47 \\
\hline 1862.5 & 71920.0 & 0.80 & -1.63 \\
\hline 1867.5 & 72164.0 & 0.96 & -1.56 \\
\hline 1872.5 & 72408.0 & 0.01 & -1.72 \\
\hline 1877.5 & 72652.0 & 0.17 & -1.68 \\
\hline 1887.5 & 73140.0 & 0.00 & -1.63 \\
\hline 1892.5 & 73384.0 & 0.87 & -1.39 \\
\hline 1897.5 & 73628.0 & 0.78 & -1.71 \\
\hline 1912.5 & 74360.0 & -0.58 & -1.73 \\
\hline 1917.5 & 74604.0 & -0.79 & -1.77 \\
\hline 1922.5 & 74848.0 & 0.75 & -1.84 \\
\hline 1927.5 & 75092.0 & 0.99 & -1.69 \\
\hline 1932.5 & 75336.0 & 0.34 & -1.81 \\
\hline 1937.5 & 75580.0 & 1.03 & -1.49 \\
\hline 1942.5 & 75824.0 & 0.54 & -1.66 \\
\hline 1947.5 & 76068.0 & 0.87 & -1.87 \\
\hline 1952.5 & 76312.0 & 0.34 & -1.28 \\
\hline 1962.5 & 76800.0 & 0.02 & -1.49 \\
\hline 1972.5 & 77288.0 & -0.09 & -1.68 \\
\hline 1992.5 & 78264.0 & 0.50 & -1.99 \\
\hline
\end{tabular}


Table TS 2. Carbon and oxygen stable isotope ratios of benthic foraminifera (Uvigerina sp.) of MD161-8.

\begin{tabular}{|c|c|c|c|}
\hline $\begin{array}{c}\text { Mean Depth } \\
\text { (cmbsf) }\end{array}$ & Age (y) & $\begin{array}{c}\delta^{18} O \\
(\% \circ V P D B)\end{array}$ & $\begin{array}{c}\delta^{13} \mathrm{C} \\
(\% \circ \mathrm{VPDB})\end{array}$ \\
\hline 32.5 & 627.7 & 2.79 & -0.49 \\
\hline 42.5 & 665.3 & 2.75 & -0.46 \\
\hline 52.5 & 702.9 & 2.89 & -0.54 \\
\hline 127.5 & 984.9 & 2.66 & -0.53 \\
\hline 147.5 & 1060.1 & 2.89 & -0.47 \\
\hline 222.5 & 1376.0 & 2.67 & -0.31 \\
\hline 227.5 & 1388.6 & 2.67 & -0.23 \\
\hline 252.5 & 1500.9 & 2.58 & -0.46 \\
\hline 257.5 & 1523.0 & 2.68 & -0.18 \\
\hline 327.5 & 1979.7 & 2.69 & -0.45 \\
\hline 337.5 & 2088.3 & 2.72 & -0.62 \\
\hline 347.5 & 2196.9 & 2.81 & -0.35 \\
\hline 357.5 & 2311.0 & 2.80 & -0.50 \\
\hline 362.5 & 2359.8 & 2.91 & -0.46 \\
\hline 367.5 & 2414.1 & 2.78 & -0.54 \\
\hline 372.5 & 2468.4 & 2.71 & -0.52 \\
\hline 377.5 & 2522.7 & 2.79 & -0.43 \\
\hline 382.5 & 2577.0 & 2.80 & -0.49 \\
\hline 387.5 & 2631.3 & 2.77 & -0.35 \\
\hline 392.5 & 2685.6 & 2.77 & -0.54 \\
\hline 422.5 & 3060.4 & 2.96 & -0.56 \\
\hline 437.5 & 3221.3 & 2.72 & -0.62 \\
\hline 442.5 & 3291.0 & 2.83 & -0.25 \\
\hline 457.5 & 3453.5 & 2.72 & -0.45 \\
\hline 472.5 & 3628.4 & 2.83 & -0.34 \\
\hline 487.5 & 3803.3 & 2.73 & -0.38 \\
\hline 497.5 & 3925.2 & 2.75 & -0.46 \\
\hline 522.5 & 4211.4 & 3.11 & -0.55 \\
\hline 527.5 & 4269.7 & 2.79 & -0.19 \\
\hline 537.5 & 4386.3 & 2.76 & -0.47 \\
\hline 552.5 & 4562.2 & 2.78 & -0.57 \\
\hline 557.5 & 4619.5 & 2.71 & -0.56 \\
\hline 567.5 & 4737.1 & 2.85 & -0.51 \\
\hline 577.5 & 4853.7 & 2.76 & -0.67 \\
\hline 587.5 & 4969.3 & 2.88 & -0.42 \\
\hline 597.5 & 5078.2 & 2.79 & -0.50 \\
\hline
\end{tabular}




\begin{tabular}{|c|c|c|c|}
\hline 612.5 & 5364.3 & 2.88 & -0.41 \\
\hline 622.5 & 5622.1 & 2.83 & -0.56 \\
\hline 627.5 & 5751.0 & 2.84 & -0.65 \\
\hline 637.5 & 6008.8 & 2.84 & -0.51 \\
\hline 647.5 & 6266.6 & 3.14 & -0.71 \\
\hline 652.5 & 6395.5 & 2.76 & -0.51 \\
\hline 657.5 & 6524.4 & 2.83 & -1.19 \\
\hline 667.5 & 6782.2 & 2.76 & -0.90 \\
\hline 672.5 & 6911.1 & 2.80 & -0.78 \\
\hline 677.5 & 7040.0 & 2.86 & -0.60 \\
\hline 687.5 & 7297.8 & 2.84 & -0.54 \\
\hline 692.5 & 7426.7 & 2.80 & -0.71 \\
\hline 697.5 & 7555.6 & 2.85 & -0.75 \\
\hline 722.5 & 8685.3 & 3.00 & -0.70 \\
\hline 727.5 & 8961.3 & 2.94 & -0.88 \\
\hline 737.5 & 9512.9 & 3.05 & -0.87 \\
\hline 742.5 & 9791.0 & 3.47 & -0.74 \\
\hline 747.5 & 10087.0 & 3.04 & -0.65 \\
\hline 752.5 & 10351.0 & 3.31 & -0.65 \\
\hline 757.5 & 10619.1 & 3.88 & -0.69 \\
\hline 782.5 & 11957.2 & 3.85 & -0.58 \\
\hline 787.5 & 12224.3 & 3.69 & -0.69 \\
\hline 797.5 & 12834.7 & 3.51 & -0.42 \\
\hline 812.5 & 13559.8 & 3.72 & -0.62 \\
\hline 822.5 & 14095.0 & 3.89 & -0.72 \\
\hline 827.5 & 14361.1 & 3.73 & -0.76 \\
\hline 832.5 & 14629.2 & 3.85 & -0.48 \\
\hline 837.5 & 14895.3 & 3.71 & -0.56 \\
\hline 847.5 & 15429.5 & 3.65 & -0.45 \\
\hline 852.5 & 15695.6 & 3.80 & -0.65 \\
\hline 857.5 & 15964.7 & 3.65 & -0.69 \\
\hline 862.5 & 16228.8 & 3.70 & -0.66 \\
\hline 867.5 & 16490.2 & 4.09 & -0.51 \\
\hline 872.5 & 16765.0 & 3.93 & -0.51 \\
\hline 882.5 & 17300.2 & 3.61 & -0.64 \\
\hline 887.5 & 17566.3 & 3.90 & -0.61 \\
\hline 892.5 & 17834.4 & 3.45 & -0.59 \\
\hline 897.5 & 18100.5 & 3.76 & -0.52 \\
\hline 922.5 & 19267.1 & 3.89 & -0.44 \\
\hline
\end{tabular}




\begin{tabular}{|c|c|c|c|}
\hline 927.5 & 19502.3 & 3.97 & -0.70 \\
\hline 937.5 & 19985.9 & 3.80 & -0.55 \\
\hline 947.5 & 20457.7 & 3.92 & -0.54 \\
\hline 957.5 & 20949.9 & 4.02 & -1.22 \\
\hline 967.5 & 21423.8 & 3.94 & -0.58 \\
\hline 977.5 & 21910.4 & 3.91 & -0.77 \\
\hline 987.5 & 22382.5 & 3.86 & -0.45 \\
\hline 997.5 & 22869.0 & 3.66 & -0.75 \\
\hline 1012.5 & 23645.6 & 3.87 & -0.72 \\
\hline 1017.5 & 24133.0 & 3.83 & -0.79 \\
\hline 1027.5 & 24952.5 & 3.66 & -0.57 \\
\hline 1037.5 & 25754.8 & 3.88 & -0.98 \\
\hline 1047.5 & 26650.9 & 3.86 & -0.54 \\
\hline 1057.5 & 27370.3 & 3.81 & -0.71 \\
\hline 1067.5 & 28177.4 & 3.81 & -0.60 \\
\hline 1077.5 & 28981.5 & 3.91 & -0.63 \\
\hline 1087.5 & 29765.3 & 3.86 & -0.53 \\
\hline 1097.5 & 30581.8 & 3.88 & -0.80 \\
\hline 1112.5 & 31607.6 & 3.83 & -0.68 \\
\hline 1117.5 & 31875.9 & 3.73 & -0.67 \\
\hline 1127.5 & 32412.4 & 3.81 & -0.74 \\
\hline 1137.5 & 32846.5 & 3.80 & -0.83 \\
\hline 1147.5 & 33485.4 & 3.75 & -1.03 \\
\hline 1157.5 & 34003.2 & 3.79 & -0.94 \\
\hline 1167.5 & 34558.4 & 3.71 & -0.83 \\
\hline 1177.5 & 35072.9 & 3.82 & -0.68 \\
\hline 1187.5 & 35631.4 & 3.35 & -1.16 \\
\hline 1222.5 & 37509.1 & 3.71 & -0.89 \\
\hline 1237.5 & 38313.9 & 3.92 & -0.72 \\
\hline 1257.5 & 39386.9 & 3.72 & -0.92 \\
\hline 1277.5 & 40459.9 & 3.69 & -0.87 \\
\hline 1297.5 & 41532.9 & 3.77 & -0.90 \\
\hline 1312.5 & 42362.0 & 3.83 & -0.89 \\
\hline 1327.5 & 43229.9 & 3.73 & -0.87 \\
\hline 1347.5 & 44383.9 & 3.74 & -0.89 \\
\hline 1367.5 & 45536.9 & 3.88 & -1.02 \\
\hline 1387.5 & 46689.9 & 3.86 & -0.85 \\
\hline 1412.5 & 48137.1 & 3.84 & -1.01 \\
\hline 1427.5 & 49007.9 & 3.77 & -1.17 \\
\hline
\end{tabular}




\begin{tabular}{|c|c|c|c|}
\hline 1447.5 & 50167.9 & 3.89 & -0.84 \\
\hline 1467.5 & 51308.8 & 3.66 & -0.92 \\
\hline 1537.5 & 55358.6 & 3.89 & -0.69 \\
\hline 1557.5 & 56519.7 & 3.77 & -1.29 \\
\hline 1577.5 & 57669.3 & 3.97 & -0.97 \\
\hline 1592.5 & 58535.5 & 3.80 & -1.14 \\
\hline 1597.5 & 58820.5 & 3.81 & -1.00 \\
\hline 1612.5 & 59720.0 & 3.58 & -1.18 \\
\hline 1617.5 & 59964.0 & 3.44 & -1.50 \\
\hline 1622.5 & 60208.0 & 3.64 & -1.08 \\
\hline 1627.5 & 60452.0 & 3.38 & -1.41 \\
\hline 1632.5 & 60696.0 & 3.67 & -1.49 \\
\hline 1637.5 & 60940.0 & 3.91 & -1.66 \\
\hline 1642.5 & 61184.0 & 3.47 & -1.39 \\
\hline 1647.5 & 61428.0 & 3.74 & -1.51 \\
\hline 1652.5 & 61672.0 & 3.34 & -1.27 \\
\hline 1657.5 & 61916.0 & 3.82 & -1.34 \\
\hline 1662.5 & 62160.0 & 3.98 & -8.09 \\
\hline 1667.5 & 62404.0 & 4.25 & -7.27 \\
\hline 1672.5 & 62648.0 & 3.86 & -1.15 \\
\hline 1677.5 & 62892.0 & 3.87 & -1.41 \\
\hline 1682.5 & 63136.0 & 3.85 & -1.63 \\
\hline 1687.5 & 63380.0 & 3.91 & -1.20 \\
\hline 1692.5 & 63624.0 & 3.85 & -1.46 \\
\hline 1697.5 & 63868.0 & 3.86 & -1.30 \\
\hline 1712.5 & 64600.0 & 4.02 & -1.23 \\
\hline 1717.5 & 64844.0 & 3.88 & -1.31 \\
\hline 1722.5 & 65088.0 & 4.04 & -1.48 \\
\hline 1727.5 & 65332.0 & 3.55 & -1.06 \\
\hline 1732.5 & 65576.0 & 3.93 & -0.96 \\
\hline 1742.5 & 66064.0 & 3.33 & -1.31 \\
\hline 1747.5 & 66308.0 & 3.89 & -1.80 \\
\hline 1757.5 & 66796.0 & 3.43 & -1.03 \\
\hline 1762.5 & 67040.0 & 3.51 & -0.96 \\
\hline 1782.5 & 68016.0 & 3.54 & -0.81 \\
\hline 1792.5 & 68504.0 & 3.42 & -2.21 \\
\hline 1797.5 & 68748.0 & 3.58 & -2.96 \\
\hline 1822.5 & 69968.0 & 3.59 & -5.94 \\
\hline 1827.5 & 70212.0 & 3.47 & -1.62 \\
\hline
\end{tabular}




\begin{tabular}{|c|c|c|c|}
\hline 1837.5 & 70700.0 & 3.66 & -2.15 \\
\hline 1842.5 & 70944.0 & 3.62 & -1.24 \\
\hline 1847.5 & 71188.0 & 3.50 & -1.24 \\
\hline 1852.5 & 71432.0 & 3.53 & -1.36 \\
\hline 1857.5 & 71676.0 & 3.67 & -2.18 \\
\hline 1862.5 & 71920.0 & 3.50 & -0.94 \\
\hline 1867.5 & 72164.0 & 3.55 & -1.11 \\
\hline 1872.5 & 72408.0 & 3.35 & -0.92 \\
\hline 1877.5 & 72652.0 & 3.56 & -0.88 \\
\hline 1882.5 & 72896.0 & 3.42 & -0.92 \\
\hline 1887.5 & 73140.0 & 3.56 & -0.97 \\
\hline 1892.5 & 73384.0 & 3.84 & -0.93 \\
\hline 1897.5 & 73628.0 & 3.62 & -0.94 \\
\hline 1912.5 & 74360.0 & 3.38 & -1.40 \\
\hline 1917.5 & 74604.0 & 3.41 & -1.01 \\
\hline 1922.5 & 74848.0 & 3.42 & -1.73 \\
\hline 1927.5 & 75092.0 & 3.72 & -3.25 \\
\hline 1932.5 & 75336.0 & 3.33 & -5.62 \\
\hline 1937.5 & 75580.0 & 3.33 & -2.67 \\
\hline 1942.5 & 75824.0 & 3.40 & -2.38 \\
\hline 1947.5 & 76068.0 & 3.60 & -1.98 \\
\hline 1952.5 & 76312.0 & 3.60 & -1.72 \\
\hline 1957.5 & 76556.0 & 3.50 & -1.36 \\
\hline 1962.5 & 76800.0 & 3.45 & -1.64 \\
\hline 1967.5 & 77044.0 & 3.81 & -1.92 \\
\hline 1972.5 & 77288.0 & 3.63 & -1.96 \\
\hline 1977.5 & 77532.0 & 3.45 & -1.92 \\
\hline 1992.5 & 78264.0 & 3.38 & -1.75 \\
\hline 1997.5 & 78508.0 & 3.72 & -1.44 \\
\hline
\end{tabular}


Supplementary Table- 3: Mineralogy and $\delta^{13} \mathrm{C}$ values of authigenic carbonate samples from MD161-15

\begin{tabular}{|c|c|c|l|}
\hline $\begin{array}{c}\text { Sample } \\
\text { depth(cm) }\end{array}$ & $\begin{array}{c}\text { Carbonate Mineralogy } \\
\text { by XRD }\end{array}$ & $\delta^{13} \mathrm{C}(\%$ VPDB) & $\begin{array}{l}\text { MgCO3 } \\
\text { (mole } \\
\%)\end{array}$ \\
\hline 2711 & High Mg calcite & -47.3 & 6.3 \\
\hline 2897.5 & High Mg calcite & -50.2 & 11.42 \\
\hline 2902.5 & High Mg calcite & -46.8 & 12.5 \\
\hline 2920 & High Mg calcite & -47.9 & 12.8 \\
\hline
\end{tabular}


Suppl. Table-4. Total organic carbon content (TOC wt \%), $\delta^{13} \mathrm{C}_{\mathrm{TOC}}(\% 0$ VPDB) and Total inorganic carbon content (TIC wt\%) in MD161-8.

\begin{tabular}{|c|c|c|c|c|c|}
\hline Depth (cmbsf) & $\begin{array}{c}\text { TOC } \\
\%\end{array}$ & TIC \% & TN \% & Depth (cmbsf) & $\delta^{13} \mathrm{C}$ \\
\hline 21 & 1.39 & 0.29 & 0.09 & 21 & -18.9 \\
\hline 39 & 1.36 & 0.28 & 0.08 & 39 & -18.5 \\
\hline 59 & 1.38 & 0.29 & 0.08 & 59 & -18.7 \\
\hline 79 & 1.31 & 0.32 & 0.10 & 79 & -18.5 \\
\hline 99 & 1.35 & 0.25 & 0.07 & 99 & -18.5 \\
\hline 121 & 1.37 & 0.29 & 0.08 & 121 & -18.7 \\
\hline 139 & 1.37 & 0.30 & 0.08 & 139 & -18.2 \\
\hline 159 & 1.38 & 0.30 & 0.08 & 159 & -18.2 \\
\hline 179 & 1.47 & 0.26 & 0.08 & 179 & -18.2 \\
\hline 199 & 1.47 & 0.30 & 0.08 & 199 & -18.2 \\
\hline 221 & 1.56 & 0.32 & 0.07 & 221 & -19.0 \\
\hline 239 & 1.42 & 0.31 & 0.07 & 239 & -18.8 \\
\hline 259 & 1.50 & 0.35 & 0.08 & 259 & -19.0 \\
\hline 279 & 1.42 & 0.30 & 0.07 & 279 & -18.9 \\
\hline 299 & 1.49 & 0.35 & 0.10 & 299 & -18.9 \\
\hline 321 & 1.53 & 0.44 & 0.09 & 321 & -19.1 \\
\hline \multirow[t]{2}{*}{339} & 1.44 & 0.36 & 0.08 & & \\
\hline & & & & 339 & -19.0 \\
\hline 359 & 1.69 & 0.44 & 0.10 & 359 & -19.5 \\
\hline 379 & 1.65 & 0.44 & 0.12 & 379 & -19.5 \\
\hline 399 & 1.78 & 0.35 & 0.11 & 399 & -19.7 \\
\hline 421 & 1.52 & 0.57 & 0.10 & 421 & -19.4 \\
\hline 439 & 1.67 & 0.56 & 0.11 & 439 & -19.7 \\
\hline 459 & 1.72 & 0.49 & 0.11 & 459 & -19.7 \\
\hline 479 & 1.74 & 0.29 & 0.11 & 479 & -20.2 \\
\hline 499 & 1.76 & 0.33 & 0.12 & 499 & -20.8 \\
\hline 521 & 1.58 & 0.57 & 0.10 & 521 & -20.4 \\
\hline 539 & 1.78 & 0.26 & 0.08 & 539 & -20.2 \\
\hline 559 & 1.81 & 0.48 & 0.10 & 559 & -20.1 \\
\hline 579 & 1.82 & 0.53 & 0.10 & 579 & -19.6 \\
\hline 599 & 1.70 & 0.60 & 0.12 & 599 & -20.9 \\
\hline 611 & 1.52 & 0.85 & 0.11 & 611 & -20.9 \\
\hline 629 & 1.53 & 0.77 & 0.10 & 629 & -21.2 \\
\hline 649 & 1.73 & 0.72 & 0.13 & 649 & -21.3 \\
\hline
\end{tabular}




\begin{tabular}{|c|c|c|c|c|c|}
\hline 669 & 1.53 & 0.70 & 0.11 & 669 & -21.4 \\
\hline 689 & 1.28 & 1.02 & 0.12 & 689 & -20.7 \\
\hline 711 & 1.38 & 0.82 & 0.10 & 711 & -20.6 \\
\hline 729 & 1.51 & 0.77 & 0.10 & 729 & -21.5 \\
\hline 749 & 1.35 & 1.14 & 0.13 & 749 & -20.7 \\
\hline 769 & 1.43 & 1.03 & 0.12 & 769 & -20.1 \\
\hline 789 & 1.30 & 1.19 & 0.11 & 789 & -19.4 \\
\hline 811 & 1.43 & 1.53 & 0.09 & 793 & -19.2 \\
\hline 829 & 1.36 & 1.63 & 0.10 & 798 & -19.3 \\
\hline 849 & 1.21 & 1.67 & 0.10 & 811 & -18.0 \\
\hline 869 & 1.17 & 1.49 & 0.09 & 818 & -17.8 \\
\hline 889 & 1.14 & 1.76 & 0.09 & 829 & -17.9 \\
\hline 921 & 1.36 & 1.53 & 0.08 & 833 & -17.9 \\
\hline 939 & 1.31 & 1.42 & 0.08 & 838 & -17.5 \\
\hline 959 & 1.32 & 1.55 & 0.08 & 849 & -17.3 \\
\hline 979 & 1.44 & 1.52 & 0.09 & 858 & -17.5 \\
\hline 999 & 1.51 & 1.67 & 0.10 & 869 & -17.5 \\
\hline 1011 & 1.46 & 1.50 & 0.09 & 878 & -17.0 \\
\hline 1029 & 1.53 & 1.30 & 0.10 & 889 & -16.7 \\
\hline 1049 & 1.68 & 1.53 & 0.12 & 893 & -17.3 \\
\hline 1069 & 1.51 & 1.60 & 0.11 & 898 & -16.8 \\
\hline 1089 & 1.39 & 1.22 & 0.07 & 921 & -16.6 \\
\hline 1111 & 1.39 & 0.49 & 0.08 & 928 & -16.6 \\
\hline 1129 & 1.48 & 0.99 & 0.10 & 939 & -16.4 \\
\hline 1149 & 1.47 & 1.25 & 0.12 & 948 & -16.9 \\
\hline 1169 & 1.41 & 1.18 & 0.11 & 959 & -15.8 \\
\hline 1189 & 1.41 & 1.47 & 0.11 & 968 & -17.0 \\
\hline 1221 & 1.84 & 0.92 & 0.12 & 979 & -16.4 \\
\hline 1239 & 1.97 & 0.80 & 0.12 & 988 & -16.1 \\
\hline 1259 & 2.02 & 0.79 & 0.12 & 998 & -15.8 \\
\hline 1279 & 1.73 & 1.21 & 0.14 & 999 & -16.2 \\
\hline 1299 & 1.86 & 1.05 & 0.15 & 1011 & -15.6 \\
\hline 1311 & 1.75 & 0.85 & 0.14 & 1018 & -15.1 \\
\hline 1329 & 1.85 & 1.11 & 0.14 & 1029 & -15.7 \\
\hline 1349 & 1.76 & 1.19 & 0.12 & 1038 & -15.9 \\
\hline 1369 & 1.67 & 0.61 & 0.11 & 1049 & -16.0 \\
\hline 1389 & 1.71 & 0.67 & 0.12 & 1058 & -16.0 \\
\hline 1411 & 1.39 & 0.77 & 0.09 & 1069 & -16.1 \\
\hline 1429 & 1.13 & 1.00 & 0.08 & 1078 & -15.7 \\
\hline
\end{tabular}




\begin{tabular}{|c|c|c|c|c|c|}
\hline 1449 & 1.33 & 0.60 & 0.08 & 1089 & -15.2 \\
\hline 1469 & 1.51 & 0.40 & 0.07 & 1093 & -15.2 \\
\hline 1489 & 1.53 & 0.69 & 0.09 & 1098 & -13.8 \\
\hline 1521 & 1.83 & 0.33 & 0.07 & 1111 & -15.0 \\
\hline 1539 & 2.01 & 0.97 & 0.12 & 1118 & -15.7 \\
\hline 1559 & 1.97 & 1.26 & 0.12 & 1129 & -16.3 \\
\hline 1579 & 1.70 & 1.54 & 0.15 & 1138 & -16.7 \\
\hline 1599 & 0.98 & 2.22 & 0.16 & 1149 & -17.2 \\
\hline 1611 & 1.54 & 0.11 & 0.07 & 1158 & -16.4 \\
\hline 1629 & 1.80 & 0.70 & 0.10 & 1169 & -16.6 \\
\hline 1649 & 1.97 & 1.86 & 0.13 & 1178 & -16.8 \\
\hline 1669 & 1.40 & 1.55 & 0.10 & 1189 & -16.9 \\
\hline 1689 & 1.37 & 1.34 & 0.09 & 1198 & -16.1 \\
\hline 1711 & 1.45 & 1.36 & 0.09 & 1221 & -16.0 \\
\hline 1729 & 1.39 & 1.07 & 0.09 & 1239 & -15.9 \\
\hline 1749 & 1.39 & 0.44 & 0.10 & 1259 & -16.3 \\
\hline 1769 & 1.42 & 0.11 & 0.10 & 1279 & -16.5 \\
\hline 1789 & 1.31 & 0.43 & 0.10 & 1299 & -16.7 \\
\hline 1821 & 1.34 & 0.48 & 0.08 & 1311 & -15.4 \\
\hline 1839 & 1.31 & 0.93 & 0.09 & 1318 & -16.0 \\
\hline 1859 & 1.16 & 0.88 & 0.09 & 1329 & -16.5 \\
\hline 1879 & 1.27 & 0.51 & 0.08 & 1349 & -16.2 \\
\hline 1899 & 1.23 & 0.80 & 0.08 & 1369 & -15.9 \\
\hline 1911 & 1.30 & 1.00 & 0.08 & 1389 & -15.9 \\
\hline 1929 & 1.21 & 0.22 & 0.07 & 1411 & -15.8 \\
\hline 1949 & 1.51 & 0.22 & 0.05 & 1429 & -15.3 \\
\hline 1969 & 1.31 & 0.89 & 0.07 & 1449 & -15.0 \\
\hline 1989 & 1.43 & 0.58 & 0.08 & 1469 & -15.7 \\
\hline \multirow[t]{11}{*}{2029} & 1.53 & 0.23 & 0.05 & 1489 & -16.9 \\
\hline & & & & 1521 & -16.9 \\
\hline & & & & 1539 & -17.6 \\
\hline & & & & 1559 & -17.7 \\
\hline & & & & 1579 & -17.6 \\
\hline & & & & 1599 & -17.3 \\
\hline & & & & 1611 & -19.0 \\
\hline & & & & 1629 & -19.6 \\
\hline & & & & 1649 & -20.8 \\
\hline & & & & 1669 & -19.2 \\
\hline & & & & 1679 & -19.0 \\
\hline
\end{tabular}




\begin{tabular}{ll}
1689 & -17.8 \\
1693 & -19.4 \\
1698 & -19.6 \\
1711 & -20.8 \\
1729 & -18.3 \\
1749 & -16.9 \\
1789 & -17.1 \\
1821 & -15.7 \\
1839 & -16.0 \\
1859 & -16.2 \\
1879 & -15.5 \\
1899 & -16.0 \\
1911 & -15.9 \\
1929 & -16.1 \\
1949 & -15.6 \\
1969 & -16.1 \\
1989 & -15.5 \\
$\mathbf{2 0 1 1}$ & -15.9 \\
\hline
\end{tabular}

